\title{
Definitions and explanatory notes
}

\section{Introduction}

This supplement gives definitions of items and units employed in the Monthly Digest of Statistics in more detail than is possible in the headings and footnotes of the tables in the publication itself.

This issue replaces the Annual Supplement published in the January 2008 edition of the Monthly Digest of Statistics, No 745. If further new data are added or changes are made in the content before the next edition of this supplement, the new data will be described in the Introduction and additional definitions will be given, where necessary, in the footnotes to the tables.

\section{NATIONAL ACCOUNTS}

The tables which follow are based on those in the Blue Book 2008 Edition and quarterly Business Investment First Release. Some of the figures are provisional and may have to be revised later; this applies particularly to the figures for 2006 onwards. Quarterly updates to National Accounts data are available within the United Kingdom Economic Accounts publication.

The accounts are based on the European System of Accounts 1995 (ESA95). The Blue Book contains an introduction to the system of the UK accounts outlining some of the main concepts and principles of measurement used. It explains how key economic indicators are derived from the sequence of accounts and how the figures describing the whole economy are broken down by sector and by industry. A detailed description of the structure for the accounts is provided in a separate ONS publication United Kingdom National Accounts: Concepts, Sources and Methods (TSO 1998). Further information on the financial accounts is given in the Financial Statistics Explanatory Handbook.

In the tables in this chapter on national income, analyses by industry are based, as far as possible, on the Standard Industrial Classification (Revised) 1992. The first aggregate measured in these tables is Gross domestic product (GDP) which measures the total economic activity taking place in UK territory. It can be viewed as incomes earned, as expenditures incurred, or as production. Adding all primary incomes received from the rest of the world and deducting all primary incomes payable to non-residents produces Gross national income (previously known as gross national product) representing the value of all incomes earned by UK residents.

ESA95, the standard European accounting framework, provides a systematic and detailed description of the UK economy. It includes the sector accounts which provide, by institutional sector, a description of the different stages of the economic process from production through to income generation, distribution and use of income to capital accumulation and financing; and the input output framework, which describes the production process in greater detail. It contains all the elements required to compile such aggregate measures as GDP, gross national income (GNI) and saving.

Each table has a section giving seasonally adjusted estimates to assist in the interpretation of the unadjusted estimates.

\section{Gross domestic product and gross national income (Tables $1.1-1.3$ )}

Table 1.1 shows the main national accounts aggregates, at current prices and chained volume measures where the reference year $2003=100$.

Table 1.2, the expenditure approach to GDP at current prices and chained volume measures at 2003 prices shows consumption expenditure by households and government, gross capital formation and expenditure on UK exports by overseas purchasers. The sum of these items overstates the amount of income generated in the United Kingdom by the value of imports of goods and services; this item is therefore subtracted to produce gross domestic product at market prices.

When looking at the change in the economy over time, the main concern is usually whether more goods and services are actually being produced now than at some time in the past. Over time, changes in current price GDP show changes in the monetary value of the components of GDP and, as these changes in value can reflect changes in both price and volume, it is difficult to establish how much of an increase in the series is due either to increased activity in the economy or to an increase in the price level. As a result when looking at the real growth in the economy over time, it is useful to look at volume (or constant price) estimates of GDP. In constant price series, for all years the transactions are re-valued to a constant price level using the average prices of a selected year, known as the base year. National Accounts currently presents chained volume measures based to 2003.

Table 1.3, the income approach to GDP shows gross operating surplus, mixed income and compensation of employees (previously known as income from employment). Taxes are added and subsidies are deducted to produce the total of the income-based components at market prices.

\section{Index numbers of output at constant market prices} (Table 1.4)

Indices of the output of individual industries and services, valued at the prices of a base year, are combined using weights proportional to the contribution of each industry 
to gross domestic product in that year in order to derive an output-based assessment of GDP.

The estimates in Table 1.4 are produced only on a quarterly, seasonally adjusted basis, except for production industries which are available monthly, unadjusted and seasonally adjusted and the services industries, which are available monthly, seasonally adjusted only. More detailed annual information is published once a year in Table 2.4 of the ONS Blue Book - United Kingdom National Accounts.

The 2003 based estimates of output in Tables 1.4, 7.1 and 7.2 are classified using industrial groups from the Standard Industrial Classification, revised 1992.

\section{Households' and non-profit institutions serving households' (NPISH) sector analysis - Distribution of income accounts (Tables 1.5 - 1.7)}

The national accounts accounting framework includes the sector accounts which provide, by institutional sector, a description of the different stages of the economic process from production through income generation, distribution and use of income to capital accumulation and financing. Tables 1.5 - 1.6 show the allocation of primary income account and the secondary distribution of income account for the households sector. Additionally, Table 1.7 shows the use of income account for the households sector.

The secondary distribution of income account describes how the balance of income is allocated by redistribution; through transfers such as taxes on income, social contributions and benefits and other current transfers. The balancing item of this account is gross disposable income (B.6g). Gross disposable income at constant prices is shown as real households' disposable income.

Table 1.7 shows, for the households sector, the use of disposable income where the balancing item is saving (B.8g).

\section{Households' and non-profit institutions serving households' (NPISH) consumption expenditure at current and constant prices (Table 1.8)}

Households' and NPISHs' consumption expenditure is a major component of the expenditure measure of gross domestic product at current and constant prices (Table 1.2).

Households' final consumption expenditure includes the value of income-in-kind and imputed rent of owner-occupied dwellings but excludes business expenditure allowed as deductions in computing income for tax purposes. It includes expenditure on durable goods, for instance motor cars, which from the point of view of the individual might more appropriately be treated as capital expenditure. The only exceptions are the purchase of land and dwellings and costs incurred in connection with the transfer of their ownership and expenditure on major improvements by occupiers, which are treated as personal capital expenditure.

The estimates of households' consumption expenditure include purchases of second-hand as well as new goods, less the proceeds of sales of used goods.

The most detailed figures are published quarterly in Consumer Trends.

\section{Change in inventories (Table 1.9)}

This table gives an analysis of the values of entries into inventories (stocks) less the value of withdrawals and the value of any recurrent losses of goods held in inventories. The analysis is presented by industry with an additional asset breakdown for the manufacturing industries.

\section{Gross fixed capital formation (Table 1.10)}

Gross fixed capital formation comprises expenditure on the replacement of, and additions to, fixed capital assets located in the United Kingdom, presented as a breakdown by sector and by asset.

\section{Business Investment (Tables 1.11 - 1.17)}

The Business Investment figures are principally based on the results of the Quarterly Capital Expenditure inquiry, but also include data from HM Revenue and Customs and other government departments.

The quarterly inquiry provides estimates for the private sector (both manufacturing and non-manufacturing) component of business investment, based on information supplied to the ONS by a sample of companies. The figures for the latest complete year and succeeding quarters are based on the quarterly inquiry, but can be revised when results from the annual surveys and GDP input-output balancing process become available. Annual surveys, such as the Annual Business Inquiry, have more comprehensive coverage by industry and are used to benchmark the quarterly survey data.

The series published are net capital expenditure figures representing capital acquisitions less receipts from sales of vehicles and other capital equipment together with expenditure on leased assets and new building work. Spending on land and existing buildings is excluded.

The private sector estimates exclude expenditure on dwellings.

The quarterly figures at current prices are revalued in chained volume terms and are also presented as seasonally adjusted series. 


\section{POPULATION AND VITAL STATISTICS}

\section{Population}

Population Estimates for mid-2007, released 21st August 2008. More information on population estimates can be found on the ONS website at: http://www.statistics.gov. uk/statbase/product.asp?vlnk=601

\section{Definition of resident population}

The estimated resident population of an area includes all people who usually live there, whatever their nationality. Members of UK and non-UK armed forces stationed in the UK are included in the population and UK forces stationed outside the UK are excluded. Students are taken to be resident at their term-time addresses.

The methodology used to update the population estimates accounts for flows of long-term international migrants. A long-term international migrant is defined as somebody who changes his or her country of usual residence for a period of at least one year.

Note: Methods and sources used by England and Wales, Scotland and Northern Ireland may differ.

The population estimates are updated annually. The current series are based on the 2001 Census.

Figures for the United Kingdom do not include the population of the Channel Islands or the Isle of Man.

Births, marriages and deaths (Tables $2.3-2.4$ )

Live births for England and Wales relate to numbers occurring in a period; for Scotland and Northern Ireland, figures relate to those registered in a period. Marriages are those solemnised in England and Wales during the calendar years shown.

By law, births must be registered within 42 days in England and Wales, within 21 days in Scotland, and within 42 days in Northern Ireland. In England and Wales, where a birth is registered later than the legal time period, and too late to be included in the count for the year of occurrence, it will be included in the count for the following year.

Birth figures for England and Wales separately, exclude events for persons usually resident outside England and Wales (242 in 2007). These events are, however, included in totals for England and Wales combined, and for the United Kingdom. From 1981 births to non-resident mothers in Northern Ireland are excluded from the figures for Northern Ireland, and the United Kingdom.
Total and infant deaths figures are all those registered in the United Kingdom in each specified period.

Stillbirths are excluded throughout.

\section{LABOUR MARKET}

The impact of Census 2001 on Labour Force Survey data (Tables 3.1, 3.9 and 3.12)

The first results of the 2001 Census, published on 30 September 2002, showed that previous estimates of the total UK population were around a million too high. This was mainly due to the over-estimation of the net flow of international migrants into the United Kingdom. Estimates of employment and unemployment levels from the LFS released before 30 October 2002 are therefore too high, with rates also affected. This led to the Labour Force Survey (LFS) reweighting their estimates to the new population figures.

In October 2008, ONS published revised LFS time series which were a result of mid-year population estimates for 2007. For more information, see the article in Economic and Labour Market Trends, November 2008: http://www.statistics.gov. uk/cci/article. asp?ld=2061.

\section{Labour market activity (Table 3.1)}

Employment - people aged 16 or over who did some paid work in the reference week of the survey whether as an employee or self-employed; those who had a job that they were temporarily away from (on holiday, for example); those on government-supported training and employment programmes; and those doing unpaid family work.

Employees - the division between employees and selfemployed is based on survey respondents own assessment of their employment status.

Self-employed - see employees.

Unpaid family workers - the separate identification of this group in the LFS is in accordance with international recommendations. The group comprises persons doing unpaid work for a business they own or for a business that a relative owns.

\section{Government-supported training and employment} programmes - comprise all people aged 16 and over, participating in one of the Government's employment and training programmes administered by Learning and Skills Council (LSCS) in England, Education and Learning Wales (ELWas) in Wales and Enterprise Companies (LECS) in Scotland. 
Unemployment - the International Labour Organisation (ILO) measure of unemployment used refers to people without a job who were available to start work in the two weeks following their LFS interview and who had either looked for work in the four weeks prior to interview or were waiting to start a job they had already obtained. This definition of unemployment is in accordance with that adopted by the $13^{\text {th }}$ International Conference of Labour Statisticians (ICLS) further clarified at the $14^{\text {th }} I C L S$, and promulgated by the ILO in its publications.

Economically active - people aged 16 and over who are either in employment or unemployed.

Economically inactive - people who are neither in employment nor unemployed on the ILO measure. This group includes, for example, all those who are looking after a home or who are retired. Although no estimates appear in this supplement, for other LFS analyses this group would also include all people aged under 16.

\section{Workforce jobs (Tables 3.2-3.3)}

The Workforce jobs (WFJ) series provides estimates for the number of jobs in the UK economy and is the source recommended by the Office for National Statistics for both the number of jobs and the industrial composition of jobs.

WFJ is the sum of employee jobs, self-employment jobs, HM forces and government supported trainees. Total workforce jobs are available by gender and broad industry. Civilian workforce jobs are available by geographical region, gender and broad industry.

The Workforce jobs series is compiled from several sources, including both household and business surveys and administrative sources. 'Employee jobs' is by far the largest component as it is mainly derived from business surveys. Self-employment figures are provided by the Labour Force Survey, as are employee jobs estimates for the construction and agriculture industries. Statistics on government-supported trainees and HM Forces come from administrative sources.

Statistics are available annually from 1959, quarterly from June 1978, and for the production industries monthly from September 1984. They are available from 1978 classified by Standard Industrial Classification. Results are currently available 11 weeks after the reference period. They are published in the Labour Market Statistics First Release. Further information from the series is published on the National Statistics website on NOMIS, online and in print in the Economic \& Labour Market Review, and in the Labour Market Statistics Regional First Releases.

The Workforce Jobs series is designed to be comparable over its whole duration, and this, together with the accuracy of its industrial information, is its major strength. However, the series cannot provide detailed industrial breakdowns, which are best sourced from the Annual Business Inquiry (ABI). Additionally, there is no information available for geographies smaller than Government Office Regions (GORs).

Employee jobs - A measure of the number of jobs of employee status mainly collected from short term employment surveys. Figures on a Standard Industrial Classification basis are available from June 1978.

Short-Term Employment Surveys (STES) - STES has been run by the Office for National Statistics since June 1996, following on from the short period employment surveys conducted by the statistics division of the Department of Employment.

Data is collected on the number of private sector employees from a sample of approximately 9,000 businesses in production industries each month and 30,000 businesses in the service and distribution industries each quarter.

The short-term series are benchmarked annually to the latest $\mathrm{ABI}$ estimates.

Annual Business Inquiry ( $A B I)$ - The $A B I$ samples approximately 78,000 businesses each year. The $A B I$ replaced the Annual Employment Survey (AES) as the source of information on employee jobs from the survey year 1999. The AES (survey date in September) and ABI (survey date in December up to 2005 and moving back to September in 2006) provides local area data down to ward level for Great Britain and the United Kingdom.

Both the ABI and STES are sampled from the InterDepartmental Business Register (IDBR). The IDBR holds details of all businesses that run a PAYE tax system or register for VAT.

Public Sector Employment (PSE) - The Office for National Statistics (ONS) produces estimates of Public Sector Employment which are compiled from a multiplicity of administrative and survey information via the Quarterly Public Sector Employment Survey (QPSES). From the summer of 2005 UK Public Sector Employment Statistics have been published quarterly on the National Statistics website with breakdowns by sector (central government, local government, public corporations) and by industry (health, education, police etc.).

In December 2005 the definitive PSE series were integrated into Workforce Jobs within the Standard Industrial Classifications (SIC) sections L, M and N; public administration and defence, education and health and social work. The rest of the PSE has been taken on in part where possible i.e. within 
division 64 (post and telecommunications) and division 92 (recreation, cultural and sporting activities). The PSE series are not benchmarked to the $A B I$.

Self-employment jobs - The Self-Employed, and the Construction and Agriculture Employee jobs series that feed into WFJ are supplied quarterly by the Labour Force Survey (LFS).

Labour Force Survey (LFS) - The LFS is a survey of households, it uses definitions from the International Labour Organisation (ILO). In any three month period a sample of approximately 135,000 people aged 16 and over in around 57,000 households are interviewed. The Construction series within WFJ is benchmarked using the Annual Business Inquiry; the Agriculture series is not benchmarked.

HM Forces - Represent the total number of UK service personnel, male and female, in HM Forces, wherever serving and including those on release leave. Administrative sources are supplied by the MOD. HM Forces fall under section $L$ within workforce jobs but are not counted as employee jobs.

Government supported trainees - This category includes all participants on government training and employment programmes who are receiving some work experience on their placement but who do not have a contract of employment (those with a contract are included in the employee jobs series). Administrative sources are supplied by the DfES, DWP, the National Assembly for Wales and the Scottish Executive.

Northern Ireland - Civilian jobs are provided by DETINI.

\section{Staff employed in the Civil Service (Table 3.4)}

The table sets out Civil Service employment by government department on a full-time equivalent (FTE) basis. The estimates count all home Civil Service employees but exclude the Northern Ireland Civil Service, the Diplomatic Service and other Crown servants.

FTE estimates are based on converting part-time employees' hours into a full-time employees' equivalent and provide a better indicator of total labour input rather than a simple headcount.

Headcount statistics are available on the same basis from the regular quarterly Public Sector Employment First Release published on the National Statistics website.

\section{Intake and outflow of UK Regular Armed Forces Personnel (Table 3.5)}

Table 3.5 shows intake to, and outflow from the UK regular armed forces. This excludes Gurkhas, full-time reserve personnel and mobilised reservists. Intake comprises all people joining the UK regular forces including re-enlistments and rejoined reservists but exclude movements between services. Outflow comprises all people leaving the UK regular forces, including death and outflow to civil life including recalled reservists on release and outflow to the Home Service battalions of the Royal Irish Regiment.

\section{UK Armed Forces Full-time Strengths (Table 3.6)}

Table 3.6 shows the full-time strength of the UK armed forces and the number of trained and untrained personnel. The figures comprise UK regular forces, Gurkhas and Full-Time Reserve Service (FTRS) personnel. FTRS are those who fill Service posts on a full-time basis while being a member of one of the reserve services, either as an ex-regular or as a volunteer. In the case of the Army and the Naval Service, these will be posts that would ordinarily have been filled by regular service personnel, in the case of the RAF, FTRS personnel also fill posts designated solely for them.

\section{Local authority staffing (Table 3.7)}

Local authorities' employment figures for England and Wales are compiled using data supplied by the quarterly local authority survey conducted by ONS. Police service data for England and Wales are obtained from the Home Office. The source for Scotland is the Joint Staffing Watch survey by the Scottish Executive and COSLA (Convention of Scottish Local Authorities).

\section{Numbers of workers employed in agriculture (Table 3.8)}

The table shows the number of persons doing agricultural work on agricultural holdings on the day of the June Survey (this includes drainage, hedging and ditching, maintenance and repair work and the marketing of produce grown), together with supervisory and office staff, seasonal or casual workers, family and hired, who are not regular workers but are working on the holding on the survey date and those supplied temporarily by agricultural contractors or gangmasters. Estimates for workers on minor holdings are included. The figures exclude gardeners, groundsmen, gamekeepers, grooms or similar estate workers, domestic staff employed in the farmhouse, schoolchildren or young workers engaged as trainees under an official scheme and not paid Agricultural Wages Board rates or more.

\section{Unemployment (Tables 3.9 and 3.12)}

Unemployed - the International Labour Organisation (ILO) measure of unemployment used refers to people without a job who were available to start work in the two weeks following 
their LFS interview and who had either looked for work in the four weeks prior to interview or were waiting to start a job they had already obtained. This definition of unemployment is in accordance with the $13^{\text {th }}$ International Conference of Labour Statisticians, further clarified at the $14^{\text {th }} I C L S$, and promulgated by the ILO in its publications.

\section{Claimant count (Tables 3.10, 3.11 and 3.12)}

The figures published for the United Kingdom, Great Britain and Government Office Regions, relate to people claiming benefit (that is Jobseekers Allowance and National Insurance credits) at Jobcentre Plus Offices on the day of the monthly count, who on that day were signed on as unemployed and satisfied the conditions for claiming benefit. Students claiming benefit during a vacation, but intend to return to full-time education, and temporarily stopped workers are excluded.

The seasonally adjusted series of claimant count figures is adjusted to allow for discontinuities in coverage. In effect, the series takes the current coverage and estimates the position as if that coverage had been in force since 1971. The seasonally adjusted claimant count figures relate only to claimants aged 18 and over, in order to maintain a consistent series. (See the November 1995 issue of Labour Market Trends. For more detail see the December 1996 issue of the Employment Gazette, now Labour Market Trends).

\section{Vacancies by industry (Table 3.13)}

The vacancy figures shown in Table 3.13 are derived from the ONS Vacancy Survey. The Vacancy Survey measures the total stock of job vacancies across the UK economy. For more details about the Vacancy Survey see the June 2003 and December 2004 issues of Labour Market Trends (now Economic and Labour Market Review) or visit the National Statistics website at http://www.statistics.gov.uk/STATBASE/ Product.asp?vlnk=9390

\section{Labour disputes (Table 3.14)}

\section{Definition of disputes}

The statistics cover stoppages of work in the United Kingdom caused by labour disputes between employers and workers, or between workers and other workers, connected with terms and conditions of employment.

Disputes which do not result in a stoppage of work, for example, work to rules and go slows, are not included in the statistics, as their effects are not quantifiable to any degree of certainty.

Stoppages involving fewer than 10 workers or lasting less than one day are excluded from the statistics unless the total number of working days lost in a dispute is 100 or more.
Stoppages over issues not directly linked to terms and conditions are excluded from the statistics though in most years this is not significant. For example, in 1986 one stoppage (a protest in the coal industry against the visit of an MP) was judged to be political and excluded from the figures. The total working days lost amounted to less than 1,000. The next known example was in 1991. This involved a boycott by self-employed market traders prompted by increased rent and changes to the market rules. The traders kept their stalls closed for about 20 weeks.

The statistics include 'lock-outs' (that is, where the employer prevents his employees from working by refusing entry to the place of work) and 'unlawful', i.e. unlawfully organised strikes. However, no distinction is made between a 'strike' and 'lockout' or between 'lawful' and 'unlawful' stoppages, principally because of the practical difficulty in determining the category into which a particular stoppage falls. It was for a similar reason that the 'official/unofficial' distinction was no longer made after 1981.

\section{Working days lost}

In measuring the number of working days lost, account is taken only of the time lost in the basic working week. Overtime work is not included, and neither is weekend working where it is not a regular practice. Where an establishment is open every day and operates two or more shifts, the statistics will record the number of working days lost for each shift. In recording the number of days lost, allowance is made for public and known annual holidays, for example, factory fortnights, occurring within the strike's duration. Allowance is not normally made for absence from work for such reasons as sickness and unauthorised leave, unless this information is readily available.

Where strikes last less than the basic working day, the hours lost are converted to full day equivalents, as are days lost by part-time workers. The number of working days lost in a stoppage reflects the actual number of workers involved at each point in the stoppage. This is, in general, less than the total obtained by multiplying the duration of the stoppage by the total number of workers involved at any time during the stoppage because some workers would not have been involved throughout.

In disputes where an employer dismisses his employees and subsequently reinstates them, the working days lost figure includes days lost by workers during the period of dismissal. For disputes where an employer dismisses his employees and replaces them with another workforce, the statistics cannot assume that working days being lost by the sacked workers continue indefinitely. In such cases the statistics measure the number of days lost in terms of the size of the replacement 
workforce; for example, where an employer initially recruits 100 workers and wishes to build up to a total of 300 , the number of working days lost on day one will be recorded as 200 and will then be progressively reduced on subsequent days, eventually to zero when the new workforce reaches the target of 300 .

\section{Number of stoppages}

There are difficulties in ensuring complete recording of stoppages, in particular for short disputes lasting only a day or so or involving only a few workers. Because of this recording difficulty and the cut off applied in the recording process, the number of working days lost is considered to be a better indicator of the impact of labour disputes than the number of recorded stoppages.

\section{Workers involved}

The figures for workers involved relate to persons both directly and indirectly involved at the establishments where the disputes occurred. Workers indirectly involved cover those who are not themselves parties to the dispute but are unable to work as a result of the dispute; workers at other sites who are indirectly affected because, for example, of a shortage of materials, or temporary lack of demand are excluded entirely. This is partly because of the difficulty in deciding to what extent a particular firm's production problems are due to the effects of a strike elsewhere or some other cause. Workers involved in more than one stoppage during a year will be included in the statistics for each stoppage in which they take part. Part-time workers are counted as whole units.

The statistics try to record the numbers of all workers involved at any time in the stoppage. For example, if, in a three-day strike, there were 200 workers involved on day one, 300 workers on day two of whom 100 were involved for the first time, and 200 on day three of whom 50 were involved for the first time, then the number of workers involved in the dispute is 350 , the sum of all those involved on the first day, and those joining for the first time on subsequent days. However, the number of workers taking strike action for the first time during a dispute cannot always be easily ascertained and in such cases the statistics record the highest number involved at any one time (300 in the above example). Taking another example, where there are 200 workers recorded as being involved in the stoppage on each of days one, two and three it may be necessary to assume that a total of 200 workers were involved although, it is possible, but unlikely, that as many as 600 workers could have been involved. For this reason, the number of workers involved in a dispute may be underrecorded. However, the estimate of the number of working days lost will, of course, be unaffected by this consideration.
A more detailed analysis of stoppages caused by labour disputes is published in June's edition of Economic and Labour Market Review.

\section{SOCIAL SERVICES}

\section{National Insurance and Child Benefit (Tables 4.1 and 4.3)}

\section{Unemployment Benefit/Jobseeker's Allowance (Table 4.1 and 4.3)}

Jobseeker's Allowance (JSA) replaced Unemployment Benefit and Income Support for unemployed people on 7 October 1996. To be entitled to Jobseeker's Allowance, a person must: be available for work, be capable of working or be actively seeking work and enter into a Jobseeker's Agreement. Men should be aged under 65 and women under 60 . You normally cannot claim Jobseekers Allowance if you are aged under 18. You also must be not currently working or if you are, be working an average of less than 16 hours a week.

Awards of JSA are either contribution-based or incomebased. Those who have paid sufficient National Insurance contributions get contribution-based JSA, at a personal rate for six months. Those who do not qualify for, or whose needs are not met by contribution-based JSA may qualify for incomebased JSA for themselves and their dependants according to need and their personal savings. Since April 2003, allowances for child dependants of income-based JSA claimants have increasingly been paid through the Child Tax Credit. The income-based element is paid as long as needed, provided that the qualifying conditions continue to be met.

\section{Sickness, Invalidity and Incapacity Benefit}

These benefits are payable to claimants who are incapable of work through illness or injury.

Since 6 April 1983, most people who are employed and paying National Insurance contributions receive Statutory Sick Pay (SSP) from their employer when off work sick.

SSP is payable for a maximum of 28 weeks. Those excluded from the SSP scheme, e.g. the self employed, unemployed, employees with short term contracts or those whose SSP has terminated but are still sick, may claim Incapacity Benefit (IB).

Incapacity Benefit replaced Sickness Benefit (SB) and Invalidity Benefit (IVB) from 13 April 1995. It is paid to people who are assessed as being incapable of work and have satisfied the contribution conditions. Neither SSP nor IB is payable for the first three days of any period of sickness. Those who do not 
satisfy the contribution conditions can still go on to receive National Insurance credits only.

To receive SB or IVB a person must have satisfied the same contribution conditions as for $\mathrm{IB}$, but in addition to this, those who were incapable because of an industrial accident or prescribed disease had their contribution conditions deemed as satisfied.

Sickness Benefit was payable for the first 28 weeks of incapacity to those who satisfied the contribution conditions, but were excluded from Statutory Sick Pay (SSP). Invalidity Benefit was payable after 28 weeks SB or SSP.

Incapacity Benefit is paid at three rates: IB Short Term (Low) (IBST(L)) paid for the first 28 weeks of incapacity; IB Short Term (High) (IBST(H)) paid for the following 24 weeks; and IB Long Term (IBLT) paid after one year. People with a terminal illness or who are receiving the higher rate care component of Disability Living Allowance receive IBLT rate from week 29. For people over state pension age, the short-term rate of IB based on Retirement Pension entitlement, is paid for up to a year. The long-term rate is not paid for people over pension age.

The number of first doctors' statements measures the number of 'new claims' and self-certificates received at local DWP offices. Cases where a certificate is received but benefit is not payable are included in the statistics as they indicate incapacity for work.

A person who is long-term sick and does not satisfy the contribution conditions for IB, may be entitled to Severe Disablement Allowance (SDA). Claims to SDA are not counted in the figures for IB.

SDA is not available to new claimants from 6 April 2001. From this point, disabled people, whose period of incapacity begins before the age of 20 (or 25 if in education or training before the age of 20), may be able to receive Incapacity Benefit without having to satisfy the National Insurance contribution conditions. SDA recipients aged below 20 at the cut-off point transferred to IB at the long-term rate from April 2002. Existing recipients can continue to receive the benefit for as long as they satisfy the conditions of entitlement for the benefit.

\section{State Pensions (Table 4.1)}

State Pensions, as the name implies, are payable on making a claim provided the state pension age (65 for men, 60 for women) has been reached and the necessary contribution conditions are satisfied.

A married woman, who does not qualify, or only partially qualified, for a pension in her own right, can receive a pension through her husband's insurance provided that the age conditions are satisfied by both and both make a claim for their pension.

\section{Widows' pensions}

This is only paid to widows already claiming as of 9th April 2001 and these are payable, only subject to certain conditions, from the date of widowhood. A widow's pension can continue unless the widow remarries, cohabits or until she reaches the age of 65 when it is replaced by a State Pension. However, between age 60 and 65 a widow may choose to receive either her widow's pension or State Pension. A widowed mother's allowance continues generally speaking so long as a widow has at least one qualifying child of school age.

\section{Widowed Mothers' Allowances}

Widowed Parent's Allowance - replaced Widowed Mothers Allowance and includes a basic allowance, an allowance for each dependant and an addition to the State Pension. Widowed Parent's Allowance is a weekly payment made to a widow, widower or surviving civil partner with dependent children. Your husband, wife or civil partner must usually have died on or after 9th April 2001. However, if you are a man and your wife died before this date, you were under 65 when she died and you did not re-marry before 9th April 2001, you can also claim Widowed Parent's Allowance.

\section{Bereavement Benefit}

Bereavement Benefit was introduced on the 9th April 2001 It is payable to both men and women. You are entitled to a Bereavement Payment if your husband, wife, or civil partner who has died paid enough national insurance contributions. If they died as the result of an industrial accident or an industrial disease, it does not matter whether they paid enough contributions or not. To get Bereavement Payment you must have been below state pension age when your husband, wife or civil partner died, or - if you were over pension age - they must not have been entitled to state retirement pension, based on their own national insurance contributions, when they died. Pension age is 60 for a woman and 65 for a man. You must have been married to your husband or wife, or in a registered civil partnership with your partner when they died.

\section{Child and Working Tax Credit (Table 4.2)}

Child and Working Tax Credits replaced Working Families' Tax Credit.

Child Tax Credit (CTC) provides support to families for 
children (up to 31 August after their $16^{\text {th }}$ birthdays) and the "qualifying" young people (those in full-time non advanced education until their $20^{\text {th }}$ birthdays) for which they are responsible. It is paid in addition to Child benefit.

Some out of work families with children do not receive CTC but instead receive the equivalent amount via child and related allowances in Income Support or income-based Jobseeker's Allowance (IS/JSA). These families are included in the figures, generally together with out of work families receiving CTC. In due course they will be "migrated" to tax credits.

Working Tax Credit (WTC) tops up earnings of families on low or moderate incomes. People working for at least 16 hours a week can claim if they (a) are responsible for at least one child or qualifying young person, (b) have a disability which puts them at a disadvantage in getting a job or (c) in the first year of work, having returned to work aged at least 50 after a period of at least six months receiving out-of-work-benefits. Other adults qualify if, for example, they are aged at least 25 and work for at least 30 hours a week.

A family is defined as being in work at the reference date if one of the adults, or a single adult, works for at least 16 hours per week. Figures for out of work families are not included in the table.

The figures in the table are estimates based on data for a random sample of $10 \%$ of individuals with awards at the reference date, extracted from the computer system on that date. The reference date will be as near as possible to the first Monday in April and December.

The final annual awards will generally not be known until after the end of the year when all the circumstances for the year are finally established. This table covers families with positive awards at the reference date. Families eligible for, and having claimed Child Tax Credits or Working Tax Credits but whose awards are tapered to zero are not included.

\section{Income Support (Table 4.3)}

Income Support is an income related benefit for people aged from 16 years up to age 60 that are on a low income.

Income Support for claimants aged 60 or over was replaced by Pension Credit in October 2003.

Conditions for entitlement are set out in the Income Support Regulations. However, in general Income Support may be paid to a person in Great Britain, aged 18 or over (or in prescribed circumstances aged 16 or 17), who has left school and whose entitlement is below their applicable amount, as specified by Income Support Regulations. Income Support is not payable where the claimant, or their partner, works for 16 hours or more a week (with certain exceptions). Savings over $£ 16,000$ usually mean you cannot get income support.

Since April 2003, allowances for child dependants of Income Support claimants have increasingly been paid through the Child Tax Credit.

\section{Pension Credit (Table 4.3)}

Pension Credit is a non-contributory, income related benefit which was introduced in October 2003 and replaced the Minimum Income Guarantee. It was designed to lift the poorest pensioners out of poverty by providing a contribution to a minimum guaranteed income for those aged 60 and over living in Great Britain and to reward those aged 65 and over who have made modest provision for their retirement.

Guarantee Credit replaced the Minimum Income Guarantee (MIG) on 6 October 2003. It provides, or contributes to, a guaranteed level of income. People aged 65 or over may be entitled to receive Savings Credit, this rewards pensioners who have modest income from savings, investments or a second pension.

\section{Family health services (Table 4.4)}

\section{Pharmaceutical services}

England and Wales. Figures cover all prescriptions dispensed by community pharmacists, appliance contractors, dispensing doctors and prescriptions submitted by doctors for items personally administered.

England. The prescription information was obtained from the Prescription Cost Analysis (PCA) system and is based on a full analysis of all prescriptions dispensed in the community in England. The vast majority of prescriptions are written by general medical practitioners in England; however prescriptions written by dentists, nurses, other non-medical prescribers and hospital doctors are included, provided they were dispensed in the community. Also included are prescriptions written in Wales, Scotland, Northern Ireland and the Isle of Man but dispensed in England. The data do not cover drugs dispensed in hospital or private prescriptions.

Further information on prescriptions dispensed in the community in England can be obtained from the Statistical Bulletin on prescriptions. The latest version covers the period 1997 to 2007 and was published in July 2008. The bulletin gives information about the total numbers and cost of prescriptions, provides full notes on sources and definitions, and presents the statistics in the form of reference tables, charts and diagrams with commentary. The text concentrates 
in changes over the last year and in addition to the areas covered in the table examines free and charged prescriptions, prescriptions per head by broad age groups, trends in leading therapeutic groups and selected drug groups.

The Information Centre for health \& social care also produces a publication, currently Prescription Cost Analysis England 2007, giving numbers of prescription items dispensed within therapeutic class at individual presentation level.

Further details about prescription statistics can be obtained from The Information Centre for health \& social care. Telephone: 08453006016 or by e-mailing prescribing@ic.nhs. uk

Scotland. From 1993 the data includes prescriptions dispensed by chemists, appliance suppliers, dispensing doctors and stock orders. Further details about prescription statistics can be obtained from the Healthcare Information Group, Information Services Division, Telephone: 0131275 6542, Fax: 01312757606.

Wales. Further details on the subjects in this table can be obtained from Vivien Trew, National Assembly for Wales, Telephone: 02920825080.

\section{Dental services}

The courses of treatment are for the General Dental Service (GDS) and the Personal Dental Service (PDS).

A Course of Treatment (COT) is defined as:

(a) an examination of a patient, an assessment of their oral health, and the planning of any treatment to be provided to that patient as a result of that examination and assessment; and

(b) the provision of any planned treatment (including any treatment planned at a time other than the time of the initial examination) to that patient.

Each CoT was associated with a single claim form (the FP17 form) which was submitted by dentists to the BSA to perform its monitoring and payment functions. Under the old contractual arrangements, counts of dental activity (CoT) were based on per item of service. As from 1 April 2006, CoT are based on the most complex component of the overall service provided.

\section{Dental services in Scotland}

The NHS General Dental Service (GDS) is usually the first point of contact that patients have with dental treatment. Patients register with an NHS General Dentist (a "High Street dentist") to receive the full range of NHS treatment provided by dentists who are independent contractors working on behalf of the local NHS Boards. There are also a number of salaried dentists working in the GDS, who provide an alternative service to the contracted General Dental Practitioners in order to meet the needs of the local population. Patients register with an NHS dentist to receive the full range of dental treatment available under the NHS GDS. All registrations lapse after 36 months, unless the patient returns to the practice. Adults make no financial contribution to their registration fees, which are paid in full by the local NHS board, and children are exempt from charges altogether. Adults are charged $80 \%$ of the cost of their treatment up to a maximum amount ( $\mathrm{f384}$ during 2005/06), unless they are exempt or entitled to remission.

\section{General ophthalmic services}

These services provide for the testing of sight and the issue of vouchers to certain eligible patients. The vouchers can be redeemed against the cost of glasses. These services operate in conjunction with the Hospital Eye Service which provides for the diagnosis and treatment of diseases or defects of the eyes and for the supply of optical appliances.

From 1 July 1986 the provision of glasses under the GOS ceased, and was replaced by a system of vouchers which can be exchanged for full or part payment against the cost of spectacles. People eligible for vouchers are children aged under 16, students aged 16-18 in full time education, patients requiring complex lenses and persons entitled to full or part remission of charges on the grounds of low income including those in receipt of Income Support, Tax Credit, Pension Credit guarantee credit and Income Based Job Seekers Allowance.

From 1 April 1989 GOS sight testing was restricted to those patients who were eligible for vouchers, plus those patients who are registered blind or partially sighted, patients who suffer from glaucoma or diabetes and those aged 40 and over who are close relatives of glaucoma sufferers. From 1 April 1999, eligibility for GOS sight tests was extended to all patients aged 60 or over.

Sights tests provided and vouchers issued for spectacles under General Ophthalmic Services (GOS) in Scotland (Table 4.4)

On 1 April 2006, a new NHS eye examination was introduced and entitlement was extended to all in Scotland. The traditional NHS "sight test" has been replaced by a comprehensive eye examination appropriate to the patient's needs. An initial eye examination is carried out (primary eye examination), and where necessary this is followed by a second eye examination (secondary eye examination). Entitlement to a voucher is, with the exception of children and those who require complex lenses, based on income. 


\section{LAW ENFORCEMENT}

\section{Recorded crime (England and Wales) (Table 5.1)}

Recorded crime statistics cover the more serious criminal offences. All offences that are triable on indictment and triable-either-way are now included as are a few summary offences which are closely linked to more serious offences (e.g. unauthorised taking of a motor vehicle; theft of a motor vehicle).

The National Crime Recording Standard was introduced nationally on 1 April 2002, with the aims to promote greater consistency between police forces in the recording of crime, and again to take a more victim-oriented approach to crime recording. The Standard had the overall effect of increasing the number of crimes recorded. The crime category most affected was violence against the person (for further details, see figure 3.7 in 'Crime in England and Wales 2003/04', http://www.homeoffice.gov.uk/rds/crimeew0304.html Home Office Statistical bulletin 7/03). Some police forces adopted the principles of the Standard in advance of its national implementation, and so this will have affected figures for earlier years, particularly 2001/02. For these reasons, recorded crime data before and after April 2002 are not directly comparable. In Table 5.1, figures prior to 2002/03 have been omitted to help prevent misleading calculations being derived from them.

The Sexual Offences Act 2003, introduced in May 2004, altered the definition and coverage of sexual offences. The Act introduced several new offences and repealed some of those which were previously in the series (for further details, see Appendix 2 in 'Crime in England and Wales 2006/07' http://www.homeoffice.gov.uk/rds/crimeew0607.html Home Office Statistical Bulletin 11/07). In particular, it redefined 'exposure' as a sexual offence.

Statistics of recorded crime represent those offences that have been recorded by the 43 Home Office police forces in England and Wales. Statistics from 2002/03 onwards contain figures for the British Transport Police. Offences recorded by nonHome Office forces such as the Ministry of Defence Police are not included unless they have also been recorded by a Home office force.

\section{Crimes and offences recorded by the police (Scot- land) (Table 5.2)}

All crimes and offences involve contraventions of the criminal law; the term 'crimes' covers the more serious criminal acts (in many cases, contraventions of Scottish common law e.g. housebreaking) and 'offences' the less serious acts (often contraventions of statutory law e.g. Road Traffic legislation).
The counting system in Scotland is offence-based rather then incident-based. In one criminal incident, several crimes or offences may occur, e.g. a house may be broken into, vandalised and the owner assaulted. In these multiple incidents, all the offences are counted rather than simply the main offence for the incident as a whole.

The definition of serious assault was amended at the start of 1990 and further revised in 2005 to improve consistency between forces. Serious assaults are included in the category 'Non-sexual crimes of violence'; minor assaults are included in the category 'Miscellaneous offences'.

In April 2004 the police implemented the Scottish Crime Recording Standard (SCRS), which means that no corroborative evidence is required initially to record a crime related incident as a crime if so perceived by the victim. Data from 2004/05 onwards shows the impact of the implementation of the SCRS which was expected to increase the numbers of minor crimes recorded by the police, such as minor crimes of vandalism and minor thefts. However it was expected that the SCRS would not have much impact on the figures for the more serious crimes such as serious assault, sexual assault, or housebreaking.

\section{Offending while on bail (Scotland) (Table 5.2)}

A legislative change that came into force on 1 April 1996 has altered the way in which offending while on bail is recorded in Scotland. Prior to this date offences of "offending while on bail " were recorded at the initial stage of the criminal justice process and were included in the recorded crime figures provided by the police. The change in legislation no longer requires such offences to be recorded at this stage; offending while on bail is now regarded as an aggravating factor at the sentencing stage. The historical recorded crime data has been revised to reflect this change to enable comparisons of recorded crime figures across years.

\section{AGRICULTURE, FOOD, DRINKS AND TOBACCO}

\section{Agricultural land (Table 6.1)}

\section{Area}

Figures relate to all registered agricultural holdings, and include estimates for those holdings not selected or not responding.

Horticultural crops include vegetables grown in the open, small fruit, hardy nursery stock, bulbs and flowers grown in the open and area under glass or plastic covered structures. 
The figures for specific crops relate to those which are actually in the ground on the date of the June Survey or for which the land is being prepared at that date. Any catch crops grown for livestock feed or for ploughing-in the period between the harvest and the sowing of the next seasons main crop will not be shown in the returns of agricultural area. The case is similar for horticultural crops.

Individual crop areas are returned to the nearest 0.1 hectare and include headlands and ditches attributable to the particular crop.

\section{Agricultural crops (Table 6.2)}

\section{Yield and production}

In England and Wales cereal production is estimated from sample surveys held in August. Production figures in Table 6.2 are rounded to the nearest 10,000 tonnes for wheat and barley and all other crops to the nearest 1,000. Sugar beet yield and production estimates are provided by British Sugar plc. Potato yield and production estimates are derived from figures provided by the British Potato Council. For remaining crops, yields are estimated by technical officers in the Department for Environment, Food and Rural Affairs (DEFRA) These are combined with area figures from the annual June agricultural census to produce production estimates. Scottish and Northern Ireland figures for cereals, oil seeds and peas are based on sample surveys of farms, and other crop production figures are based on the estimated yields of crop reporters. Provisional estimates are prepared for all countries in October. Final UK figures are normally published in early January in the year following the harvest.

\section{Horticultural crops (Table 6.2)}

\section{Cropped area and production}

The area is the "planted" area, on which the crops are actually growing, rather than the Ordnance Survey "field" area.

The yield referred to is the average tonnage actually harvested, or yet to be harvested, for each "planted" hectare.

Harvested yields are reduced to exclude any "pre-harvest wastage" such as crops left on the trees/ in the ground, to equate to all produce that has some value. For example, crops to be sent for juicing, or for stockfeed, are included.

Production in England and Wales is calculated by multiplying the yield estimates supplied by the appropriate planted area. These areas are based on one or more of the regular surveys covering horticultural crops and estimates made by a Consultancy.
Production in the UK is based on England and Wales data, plus data from the devolved authorities: The Scottish Government, Rural and Environment Research and Analysis Directorate, and the Department of Agriculture and Rural Development (Northern Ireland).

In Table 6.2, yields are estimated average gross yields, i.e. the weight of crop that was available for harvesting from each hectare cropped during a single crop year. No deductions are made for the possibility that some of the crop was not harvested or for losses following harvest.

Gross production is the product of yields and field areas. For some vegetable crops, the areas under production may produce more than one crop during a single season and will therefore be greater than the areas measured by the June survey (i.e. Table 6.1) by a factor equalling the number of crops harvested in any given year. Also, some areas may be double cropped (one crop followed by a different crop). Figures represent the maximum available supply during a single crop year, nominally the period 1 June to 31 May, the period during which the bulk of the crop is harvested, although the short extension of two or three weeks that may occur at either end of this nominal period would also be included in the crop year totals.

\section{Livestock (Table 6.3)}

The table shows the number of cattle, sheep, pigs and poultry as returned by occupiers of agricultural holdings defined previously under the heading 'Agricultural land'.

In Table 6.3, 'Barren sows for fattening' in Northern Ireland were included with 'All other pigs' prior to 1993.

Animals slaughtered and meat produced (Table 6.4)

\section{Animals slaughtered}

The figures are those of animals and poultry slaughtered in the United Kingdom, including imported fat animals. They are derived from returns recording slaughtering in licensed slaughterhouses, including bacon factories. Unrecorded domestic slaughter and slaughtering knackeries are excluded, as are animals not slaughtered for human consumption.

\section{Meat produced}

The figures represent the estimated production of carcass meat and offal from slaughtering, as defined in the preceding paragraph, and from information available on dressed carcass weights. Pig meat used for the production of bacon and ham is excluded. 


\section{Cereals and cereal products (Table 6.5)}

\section{Sales of home-grown grains for food}

For wheat the receipts of homegrown supplies by flour millers are shown and small quantities subsequently sold again for animal feed are therefore included. For barley the receipts of home-grown supplies by brewers, maltsters, flakers, roasters, distillers and pot barley manufacturers are shown and exported supplies are included. For oats the receipts by oatmeal millers of home-grown supplies for processing into human food are shown.

\section{Wheat and oat milling}

The tables show the quantities of home-produced and imported wheat milled and the amount of flour produced; the resulting production of wheat offals appears in the table of animal feedingstuffs. Stocks of wheat and flour include wheat and flour expressed in terms of wheat held by flour millers, cereal breakfast foods manufacturers, and importers and dealers. Flour disposals include exports. The stocks held by importers and dealers are included.

Only the quantities of oats used in establishments milling primarily for human food are included in the series described as oats milled. The products of oat milling are similarly restricted to all cuts of oatmeal, flakes, rolled oats, oatflour, groats and any other product produced for human food. Stocks of oats are those held by main processors, including oatmeal millers, provender millers and compound feedingstuffs manufacturers. The provender millers' figures relate to Great Britain only. Stocks held by importers and dealers are also included.

\section{Barley}

Disposals for food and brewing refer to the quantities of home-grown and imported grain used by brewers, maltsters, flakers, roasters, distillers and pot barley manufacturers. Exports are included. Stocks are those held by main processors, including brewers, maltsters, distillers, provender millers and compound feedingstuffs manufacturers. The provender millers' and compounders' figures are in respect of Great Britain only. Stocks held by importers and dealers are also included.

\section{Breakfast cereals}

Figures exclude oatmeal and oatmeal flakes.

\section{Compound feedingstuffs (Table 6.6)}

The figures relate to the United Kingdom; only production for commercial sale is included. Compound feedingstuffs include grain balancers and concentrates.

\section{Potatoes (Table 6.7)}

The figures relate to the United Kingdom; those for Great Britain have been provided by the British Potato Council, and those for Northern Ireland by the Department of Agriculture for Northern Ireland.

Sales of potatoes from farms are the quantities sold for food, for processing and for export. They include an estimate for human consumption in farm households and the surplus potatoes fed to livestock or processed under the Potato Industry Development Council Order of 1997 (prior to 1997 this was the Potato Marketing Scheme implemented under the Agriculture Marketing Act, 1958). Production on allotments and gardens, potatoes used for seed, potatoes fed to livestock outside the schemes and surpluses for which compensation has been paid, are excluded.

Disposals for food in the United Kingdom are the total quantities of potatoes moving into human consumption from all recorded sources, together with estimates of unrecorded sales. Potatoes processed for export are included within the export figures.

\section{Sugar (Table 6.7)}

Production relates to white and raw sugar (in terms of white) from home-grown sugar beet, within quota as recorded by British Sugar plc.

Disposals for food in the United Kingdom are adjusted by the net trade in imports/exports of sugar contained in processed products and refer to the total UK consumption, excluding use by non-food industries.

The "Total Disposals" figure relates to the total UK consumption, including non-food industries.

"Stocks" include imported and home-produced supplies of refined and raw sugar (in terms of refined) held in the United Kingdom

\section{Glucose (Table 6.7)}

The figures cover the production of liquid and solid glucose and dextrose monohydrate.

\section{Bacon and ham (Table 6.8)}

Production figures relate to the output of curing factories from both home-killed and imported carcasses. 


\section{Meat stocks (Table 6.8)}

Beef and veal, mutton and lamb, poultrymeat.

Until March 2006 the figures represent the stocks of meat from home-produced and imported sources held in public cold stores, including stocks of beef held for intervention.

No information is available on stocks of these commodities held in cold stores reserved for private concerns. Tremendous changes in the food distribution network and emergence of the very large retailing chains with their own extensive storage facilities means that the stocks held in them may be considerable.

The stocks held in Public Coldstores in the United Kingdom survey was discontinued in March 2006. As a result, stocks data is no longer published.

\section{Fish (Table 6.9)}

Fresh and frozen UK landings of fish are expressed in terms of live weight equivalent.

\section{Milk and milk products (Table 6.10)}

\section{Milk}

The figures cover milk sold for use as liquid milk and the manufacture of milk products. The quantity consumed by farm households and used on farms for butter and cream production or calf rearing is excluded.

\section{Milk products}

Production of dairy products relates to the output of UK dairy companies and is based on the volume of whole milk and milk fractions used to make each product. Farm production of dairy products is excluded.

\section{Chocolate and sugar confectionery (Table 6.11)}

Disposals are consumption figures combined with exports. Figures were collected by the Biscuit, Cake, Chocolate and Confectionery Alliance (BCCCA), which no longer exists. Data was not collected after December 2007.

\section{Tea (Table 6.11)}

Disposals are the quantities moving into consumption and exclude exports. Stocks comprise tea held in public and private warehouses and amounts held by primary wholesalers; these data are compiled by DEFRA from data supplied by the International Tea Committee (ITC).

\section{Raw coffee (Table 6.11)}

Disposals are estimated as imports of raw coffee plus the decrease in stocks of raw coffee in public warehouses, in transit to such warehouses, in imports not landed and manufacturers' stocks. They include coffee re-exported from the United Kingdom. The data on stocks is from two DEFRA surveys of coffee stocks (relating to stocks held by manufacturers and those held in public warehouses).

\section{Tobacco products (Table 6.12)}

The figures are supplied by HM Revenue and Customs. The statistics relate to numbers of cigarettes and weight of other tobacco products. Figures are derived from duty payment systems and therefore exclude personal importations. Data relate to releases at the time they become liable to excise duty. Products may then be stocked duty paid before consumption. Releases tend to be higher in the period immediately before the Budget and in the period before the tobacco manufacturers increase their prices.

\section{Alcoholic drinks (Table 6.13)}

The figures are supplied by HM Revenue and Customs. Quantities are derived from duty and therefore exclude personal importations. From January 1993, as a result of the introduction of the European Single Market, data relating to imports from EC countries have had to be estimated from duty receipts and figures are therefore less reliable than previously.

\section{Beer}

Data are shown for the quantity of beer produced in the United Kingdom and for the quantity released for home consumption, which includes commercial imports. Since June 1993 duty has been charged as beer leaves the brewery or other registered premises. Previously duty was charged at an earlier stage (the worts stage) in the brewing process, and an allowance was made for wastage.

\section{Wine of fresh grapes}

Wine is any fermented beverage made from fresh grapes, and includes fortified wines and vermouths. The figures show the net quantities of still table and fortified wine and sparkling wine released for home consumption.

\section{Made-wine}

Made-wine is any fermented beverage other than cider and perry, wine of fresh grapes and beer. An example is 'British sherry', which is made from imported grape concentrate. Coolers with strength of 1.2 per cent - 5.5 per cent alcohol by volume are shown separately. Coolers include alcoholic 
lemonade and similar products of appropriate strength. From 28 April 2002, duty on spirit-based 'coolers' is charged at the same rate as spirits per litre of alcohol. Made wine coolers include only wine based 'coolers' from this period.

\section{Cider and perry}

This is cider and perry of strength less than 8.5 per cent of alcohol by volume obtained from the fermentation of apple or pear juice.

\section{Spirits}

Home-produced whisky. These figures refer to spirits matured in warehouse for three years or more certified as Scotch or Northern Irish whisky released for home consumption.

Other. These figures relate to all other spirits released for home consumption, including imports. From 28 April 2002 Spirit-based RTD (Ready to Drink) products were dutied at the same rate as spirits per litre of alcohol. Details on clearances prior to 28 April are included in the made wine coolers products.

Production figures show the quantity of potable spirits distilled after maturation for consumption, separated into homeproduced whisky and other spirits.

All figures for spirits are given in hectolitres of pure alcohol. A standard whisky is 40 per cent alcohol by volume.

\section{Further references}

Monthly bulletins covering duty paid clearances and receipts for most excise goods, betting and gaming, environmental taxes, air passenger duty and VAT receipts are published and are available free from HM Revenue and Customs website at www.uktradeinfo.com

A more detailed analysis of the receipts and activities of the department are available in HM Revenue and Customs Annual Report published by The Stationery Office. Details can also be found on HMRC website at www.hmrc.gov.uk

\section{PRODUCTION, OUTPUT AND COSTS}

\section{Output of the production industries} (Table 7.1)

This index is prepared by the Office for National Statistics with the help of statistical divisions of other government departments. From the publication of the quarterly national accounts data-set on 30 June 2006, the index has been published with the year 2003 as the reference year. The first monthly publication on this basis was in early July 2006, in respect of April 2006 data.

All series are available annually, quarterly and monthly from 1994 but most series are available for earlier years. Data are published on the National Statistics website, www.statistics. gov.uk.

The index is intended to provide a general measure of monthly changes in the volume of output of the production industries, which comprise Sections C - Mining and quarrying, D Manufacturing and E - Electricity, gas and water supply of the $\operatorname{SIC}(2003)$.

Currently the loP index is a weighted average of around 79 separate indicators, each of which describes the activity within a sector of industry. Most of the data for the manufacturing industry is compiled from a comprehensive system of monthly production inquiries (MPI) to industry conducted by the ONS. From March 2008, as part of a wider reprioritisation of ONS business, the sample size for the MPI was reduced by approximately 17 per cent (this reflected the changing structure of the economy and the reduction in the size of the manufacturing sector over time). At the same time a:

- $\quad$ number of methodological improvements were introduced to maintain the quality of the higher level aggregates of the loP; and

- $\quad$ a new loP industry structure was implemented to ensure that the lowest level of detail published would consist of industries with larger sample sizes, lower standard errors and increased quality.

Further details of the methodological changes (and their impact on the loP) can be found on the National Statistics website at:

http://www.statistics.gov.uk/statbase/Product.asp?vlnk=6230

Annual chain-linking is used to combine the individual production series. Each industry has been given a weight proportional to its value added in the previous year derived from the input-output tables. The latest set of weights available is for the year 2003 .

The level of production is expressed as a percentage of the average monthly production in 2003. All current value data are deflated using the appropriate producer price indices and export deflators. The seasonal adjustment process ensures that different months' output can be compared by adjusting for the number of working days in each month and for the normal seasonal pattern. The program X-II ARIMA is used to 
carry out seasonal adjustment of the loP. The adjustments are designed to eliminate normal month to month fluctuations and thus to show the trend more clearly.

\section{Industrial classification}

The industrial analysis of the index at a published group level is consistent with the UK Standard Industrial Classification of Economic Activities - UK SIC (2003) to which reference should be made for a description of each industrial group.

\section{Market sector analysis}

At the time of the introduction of the rebased, chain-linked IoP series (end September 2003), the market sector categories were revised to be consistent with the Eurostat approved 'main industrial groupings'. 'Durable goods' was replaced by 'Consumer durables', 'Non-durable goods' by 'Consumer non-durables', 'Investment goods' by 'Capital goods' and 'Intermediate goods' by 'Intermediate goods and energy'. It is important to note that this change is not simply to do with descriptions but encompasses a reallocation of four-digit industries classified to the groupings. Data on the new basis are available from 1994.

\section{Output per filled job (Table 7.2)}

UK output per filled job is the ratio of Gross Value Added (GVA) at basic prices and productivity jobs.

The methodology used to produce the productivity jobs indices has been developed with the aim of producing a jobs measure that is consistent with the output measure used in calculating output per job estimates. Productivity jobs are calculated based on enterprise level employee jobs and selfemployed jobs, including both full-time and part-time workers as full units and differ from the Workforce Jobs series. The employees' part of productivity jobs is now constrained to the employees' part of Labour Force Survey (LFS) jobs at the whole economy level. Members of HM Forces and Governmentsupported trainees are also included in the indices.

Productivity data are available for the UK whole economy, production manufacturing and service sections. Output per job data is published on a monthly basis for manufacturing, and on a quarterly basis for the whole economy, production, manufacturing and service sections. Regional productivity estimates are available on an annual basis.

Data are also published in the Productivity First Release, Labour Market Integrated First Release, Economic Trends and Labour Market Trends. Data are published as seasonally adjusted indices, where 2003 is the base year.
The full productivity data sets and related articles can be found on the National Statistics website at www.statistics.gov. uk/productivity.

\section{Productivity and unit labour costs (Table 7.3)}

Manufacturing unit wage costs estimates are based on the seasonally adjusted monthly Average Earnings Index, manufacturing productivity jobs and the manufacturing index of production. Whole economy unit wage costs index estimates are based on GVA at basic prices, total wages and salaries, and LFS Employment. Manufacturing data are released on a monthly basis and whole economy data are quarterly.

Data are also published in the Productivity First Release, Labour Market Integrated First Release, Economic Trends and Labour Market Trends.

An index of unit labour costs is published on a quarterly basis for the whole economy. The index uses the same methodology as is applied to calculate unit wage costs, but employers' social contributions minus employment subsidies are added to the wages and salaries figure prior to calculation.

Data are published as seasonally adjusted indices, where 2003 is the base year.

The full productivity data sets and related articles can be found on the National Statistics website at www.statistics.gov. uk/productivity.

\section{ENERGY}

Inland energy consumption: primary fuel input basis (Table 8.1 )

\section{Coal}

Consumption by fuel producers plus disposals (including imports) to final users, plus solid renewable sources of energy, and net foreign trade and stock change in other solid fuels.

\section{Petroleum}

Production plus net imports minus marine bunkers, plus stock change. Figures exclude petroleum used for non-energy purposes.

\section{Natural gas}

Includes gas used during production (e.g. waste and own use for drilling, pumping and production operations) but excludes 
gas flared or re-injected. Includes colliery methane, but not landfill and sewage gases. Includes net imports and stock changes. Figures exclude gas used for non-energy purposes.

\section{Primary electricity - nuclear}

Electricity generated (net of electricity used on works) by nuclear power stations belonging to BNFL Magnox and British Energy.

\section{Primary electricity - hydro-electricity and wind}

Electricity generated (net of electricity used on works) by natural flow hydro-electric power stations (i.e. excluding pumped storage stations) owned by major power producers and other generators and by wind turbines.

\section{Primary electricity - net imports}

Electricity imported from, less electricity exported to, countries outside the United Kingdom.

\section{Conversion to oil equivalent}

In expressing fuel consumption in tonnes of oil equivalent, each fuel is converted using its gross calorific value, on the basis of 1 tonne of oil equivalent being equal to 41.868 Gigajoules (GJ).

The estimated gross calorific values used to convert the statistics are published annually in the Digest of United Kingdom Energy Statistics.

The conversion factors used are:

$$
\begin{aligned}
1 \text { tonne of oil equivalent } & =10^{7} \text { kilocalories } \\
& =396.83 \text { therms } \\
& =41.868 \text { gigajoules }(\mathrm{GJ}) \\
& =11630 \mathrm{kWh}
\end{aligned}
$$

Primary electricity is presented in oil equivalent as the energy content of the electricity produced (the energy supplied basis). For nuclear stations allowance is made for the thermal efficiency of nuclear stations.

\section{Temperature corrections}

The adjusted total inland energy consumption series includes temperature corrections for coal, petroleum and natural gas. Nuclear and hydro-electricity and net imports of electricity are not corrected for temperature.

\section{The corrections used are:}

Temperature correction per degree Celsius above the long term temperature average for the month:

$$
\begin{array}{ll}
\text { Coal } & 2.1 \% \\
\text { Petroleum } & 0.7 \% \text { (June-Aug) } \\
& 1.8 \% \text { (Sept-May) }
\end{array}
$$

Natural gas is corrected based on a methodology developed by BG Transco.

\section{Supply and use of fuels (Table 8.2)}

\section{Production of primary fuel}

Coal. Includes all grades of coal produced by all UK coal producers at mines and opencast sites. The main producers are UK Coal plc., Powerfuel Mining Ltd., Maltby Colliery Ltd., Celtic Energy Ltd., and The Scottish Coal Company Ltd. Slurry is included in the production figures.

Petroleum. Crude oil, condensates (C5 or heavier) and petroleum gases, ethane (C2), propane (C3), and butane (C4), obtained from the onshore processing of associated and nonassociated gas.

Natural gas. Indigenous natural gas (methane) production includes own use for drilling, pumping and production operations but excludes gas flared, vented or re-injected.

Primary electricity. Nuclear and hydro-electricity and electricity from wind as described under Inland energy consumption but excluding any net imports of electricity.

\section{Non-energy use}

Petroleum products and natural gas not used as fuels, i.e. feedstock for petroleum chemical plants, industrial and white spirits, lubricants, bitumen, waxes, petroleum cokes and miscellaneous products.

\section{Total primary energy}

This assesses the energy content of the total input to the economy of primary fuels and equivalents. It includes energy used and lost in the conversion of primary fuels to secondary fuels (for example in power stations and oil refineries), energy lost in the distribution of fuels (for example in transmission lines) and energy conversion losses by final users.

The energy content of primary fuels consumed by secondary fuel producers consists of their energy inputs of coal, petroleum and natural gas plus the energy equivalent of the electricity produced by nuclear and hydro-electricity stations, as defined above under 'Oil equivalents'. 


\section{Final consumption}

This measures the energy content of inputs of fuels (primary or secondary as appropriate) to final users. Thus it is net of fuel industries' own use and conversion, transmission and distribution losses, but it includes losses in conversion by final consumers. Detailed definitions of the final consuming sectors are given in the annual Digest of United Kingdom Energy Statistics (The Stationery Office), prepared by the Department for Business Enterprise and Regulatory Reform.

\section{Coal: supply (Table 8.3)}

\section{Deep-mined coal}

Production figures relate to saleable output from deep mines including coal obtained from working on both revenue and capital accounts. All licensed collieries (and British Coal collieries prior to 1995) are included, even where coal is only a subsidiary product.

\section{Opencast coal}

The figures cover saleable output and include the output of sites worked by private operators under licences as well as the output of sites licensed for the production of coal as a subsidiary to the production of other minerals.

\section{Other}

Estimates of slurry etc. recovered and disposed of from dumps, ponds, rivers etc.

\section{Coal: imports and exports (Table 8.3)}

The figures are derived from returns made by importers and exporters to HM Revenue and Customs, and published in greater detail in Annex G of the Digest of UK Energy Statistics (The Stationery Office).

\section{Coal: inland consumption (Table 8.4)}

\section{Statistical Calendar}

The statistical calendar determines which weeks are included in the 4 or 5 week statistical months. The coal industry as a whole has adopted the 4-4-5 week statistical calendar formerly used by British Coal.

\section{Collieries}

Coal used for boilers, colliery power stations and other purposes.

\section{Electricity generators}

Coal used for all purposes at power stations belonging to major power producing companies (see Electricity supply industry below).

\section{Heat generation}

Coal used to generate heat which is then sold under provision of a contract.

\section{Coke-ovens}

Coal carbonised, consumed for other purposes or lost in cleaning at coke ovens.

\section{Other conversion industries}

Consumption of coal at low temperature carbonisation plants and briquette works.

\section{Industry}

Coal used for all purposes at other industrial establishments. Figures relate to colliery and opencast disposals, and estimated proportions of steam coal imports, and imports of anthracite.

\section{Domestic}

House coal: figures relate to colliery and opencast disposals and include coal supplied free of charge or at reduced prices to miners, officials, etc. in the coal industry. They also include estimated proportions of steam coal imports.

Other: figures include colliery and opencast disposals of anthracite and dry steam coal to merchants plus disposals of imports of anthracite.

\section{Miscellaneous}

Colliery and opencast disposals to commercial public administration and non-industrial establishments, including agriculture.

\section{Electricity generators}

Electricity generators covered in this table are "major power producers" i.e. companies whose prime purpose is the generation of electricity. Companies whose main business is not electricity generation, the electricity being produced mainly for that company's own use, are excluded from this definition. A full list of the generating companies covered by this table is to be found at Footnote 1 to Table 8.6. 


\section{Natural gas production and supply (Table 8.5)}

This table shows the flow of gas from the point of production to consumption in the UK. As such the data for the upstream gas industry represents the flow of gas from production at offshore and onshore fields as well as imports and exports of gas, changes in pipeline stocks, etc. to give details of net gas available at UK gas terminals for consumption within the UK. The downstream gas industry section shows the onward transmission of this gas through the high-pressure National Transmission System and other dedicated direct supply lines between producers and major consumers towards final consumption. The data are gathered from different sources, and as such, differences arise in the recording of the volumes of gas moving at the various points of the flow. More detail on the causes and size of these differences can be found in the DECC publication, the Digest of United Kingdom Energy Statistics 2008 Chapter 4, paragraphs 4.47 to 4.50 .

\section{Electricity supply industry (Table 8.6)}

Electricity generators covered in this table are "major power producers" i.e. companies whose prime purpose is the generation of electricity. Companies whose main business is not electricity generation, the electricity being produced mainly for that company's own use, are excluded from this definition. A full list of the generating companies covered is to be found at Footnote 1 to this table.

\section{Fuel used}

The factors used for conversion to oil equivalent are given under 'Oil equivalents', above.

\section{Own use}

The difference between total electricity generated and electricity supplied, and the electricity used at the works for lighting and auxiliary power, and for pumping at pumped storage stations.

\section{Total electricity available}

Electricity supplied from major power producers plus purchases from other UK producers plus net imports from overseas.

\section{Sales of gas and electricity: public supply (Table 8.7)}

Gas sales include adjustment to the quantities billed to allow for the estimated consumption remaining unread at the end of each period.

Sales of electricity are less than total electricity available because of losses in transmission and distribution etc., and include consumption by the supply industry's offices and retail outlets. They allow for electricity consumed but not billed in the period.

\section{Petroleum (Tables 8.8 - 8.9) \\ Total indigenous production}

This is the aggregate amount of:

- crude oil produced both onshore and offshore from the UK part of the Continental Shelf including any petroleum gases and condensates separated from the oil at subsequent processing stages (prior to refining). This quantity is as recorded before any deduction for utilities use or adjustment for stock change on platform (including tanker-loading systems) or losses;

- condensates from gas fields (production is measured at the land terminal separation plant after the gas has been processed and condensates extracted).

\section{Imports and exports}

The information given under the headings "imports" and "exports" are the volumes recorded by importers and exporters of oil. These amounts may differ from the import and export figures recorded by HM Revenue and Customs. These differences can arise because of timing differences between actual and declared movements. The HMRC also include re-exports. Re-exports are products that have been imported from another country, and stored in the UK prior to being exported out of the UK. Thus these exports would not have been produced in the UK.

\section{Inland deliveries into consumption}

Deliveries of all petroleum products in the United Kingdom and the Channel Islands including petroleum substitutes marketed by the petroleum industry. Coal tar fuels, natural gas (methane) and refinery fuel are excluded. Otherwise, the figures are inclusive of the petroleum industry's own use.

Gas/diesel and fuel oils used in coastal and fishing craft are included in inland deliveries, but deliveries under contracts for ships engaged in foreign trade are excluded.

\section{Products used as fuel}

Propane - hydrocarbon containing three carbon atoms (C3H8), gaseous at normal temperature but generally stored and transported under pressure as a liquid. Used mainly for industrial purposes and some domestic heating and cooking. 
Butane - hydrocarbon containing four carbon atoms ( $\mathrm{C} 4 \mathrm{H} 10)$, otherwise as for propane. Additional uses - as a constituent of motor spirit to improve volatility and as a chemical feedstock.

Naphtha (light distillate feedstock) for gasworks - petroleum distillate boiling predominantly below $200^{\circ} \mathrm{C}$.

Aviation spirit - specially blended light by hydrocarbons intended for use in aviation piston-engined power units, including bench testing of aircraft engines.

Motor spirit - blended light petroleum distillates used as a fuel for spark-ignition internal combustion engines other than aircraft engines.

Aviation turbine fuel - specially refined kerosene intended for use in aviation gas-turbine power units.

Burning oil (kerosene or paraffin) - refined petroleum distillate intermediate in volatility between motor spirit and gas oil, used for lighting and heating. Excluding distillates which are included under white spirit and kerosene used for lubricant blends.

Gas/diesel oil - petroleum distillate having a distillation range intermediate between kerosene and light lubricating oil.

- $\quad$ Derv (Diesel Engine Road Vehicle) fuel-gas/diesel oil for use in high-speed, compression-ignition engines in road vehicles subject to Vehicle Excise Duty;

- $\quad$ Other - used in furnaces for the production of heat (e.g. for central heating) in engines of vehicles not subject to Vehicle Excise Duty (e.g. diesel locomotives, tractors, earth-moving equipment) and in stationary diesel engines and gas turbines (e.g. for the generation of electricity and for air compressors, etc.). Also includes marine diesel oil - a heavier type of gas oil suitable for heavy industrial and marine compression-ignition engines.

Fuel oil - heavy petroleum distillates or petroleum residues or blends of these used in furnaces for the production of heat or power. Excluding fuel oil for grease making or lubricating oil and fuel oil sold as such for road-making.

\section{Products not used as fuel}

Feedstock for petroleum chemical plants - all petroleum products intended for use in the manufacture of petroleum chemicals. (A deduction has been made from the deliveries equal to the quantity of feedstock used in making the conventional petroleum products which are produced during the processing of the feedstock).
White spirit - a highly refined distillate with a boiling range of about $150^{\circ} \mathrm{C}$ to $200^{\circ} \mathrm{C}$ used as a paint solvent and for dry cleaning purposes, etc.

Industrial spirits - refined petroleum fractions with boiling ranges up to $200^{\circ} \mathrm{C}$ dependent on the use to which they are put, e.g. seed extraction, rubber solvents, perfume, etc.

Lubricating oils (and greases) - refined heavy distillates obtained from the distillation of petroleum residues. Includes liquid and solid hydrocarbons sold by the lubricating oil trade, either alone or blended with fixed oils, metallic soaps and other organic and/or inorganic bodies.

Bitumen - the residue left after the production of lubricating oil distillates. Used mainly for road-making and building construction purposes. Includes other petroleum products, creosote and tar mixed with bitumen for these purposes and fuel oil sold as such for road-making.

Petroleum waxes - includes paraffin wax, which is a white crystalline hydrocarbon material of low oil content normally obtained during the refining of lubricating oil distillate, paraffin scale, slack wax, microcrystalline wax and wax emulsions. Used for cable manufacture, polishes, food containers, wrappings, etc.

Petroleum cokes - carbonaceous material derived from hydrocarbon oils, uses for which include electrode manufacture. An unknown quantity of this product may be used as a fuel.

Miscellaneous products - includes aromatic extracts, defoament solvents and other minor miscellaneous products.

\section{COMMUNICATIONS}

\section{Telephones (Table 9.1)}

Wholesale Line Rental products give Communications Providers the ability to offer their own branded service to customers using Openreach wholesale products. The Communication Provider has responsibility for the commercial relationship with the customer but Openreach supplies and maintains the lines to the customer premises on behalf of the Communications Provider and will bill the Communications Provider.

CPS (Carrier Pre-Selection) allows the customer to choose which telecom's provider is wanted to carry the phone (voice) calls. The existing 'phone numbers are kept and the customer continues to make calls as usual. CPS uses network access technology, so traffic originating from the phone will be 
routed directly to the customer's chosen network with no need for prefix codes. The "selection" of the preferred provider is done automatically at point of entry (the local exchange) to the public voice network.

Calls to southern Ireland are classed as International calls.

\section{Radio Listening (Table 9.2)}

'Weekly reach' is the number in thousands or as a percentage of the UK/area adult (15+) population who listen to a radio station for at least five minutes in the course of an average week.

'Total hours' is the overall number of hours of adult (15+) listening to a station in the UK/area in an average week.

'Average hours per head' is the total hours of listening to a station during the course of a week averaged across the total adult (15+) population of the UK/area.

'Average hours per listener' is the total hours of listening to a station during the course of a week averaged across all those listening to the station for at least 5 minutes.

'Share of listening' is the percentage of total listening time accounted for by a station in the UK/area in an average week.

\section{The Internet (Table 9.3)}

Taken from ONS's Internet access 2008; Households and Individuals First Release.

'Selected uses of the internet' illustrates the online activities of individuals, categorised by age group, who have used the Internet in the 3 months prior to interview.

'Internet purchases by adults' is asked of individuals who have ever used the Internet and have bought or ordered goods or services over the Internet, for private use, in the 12 months prior to interview.

\section{Household Digital Television (Table 9.4)}

Digital TV take-up figures are based on GfK consumer research. The GfK ownership survey incorporates a panel of 14,000 homes screened quarterly via the internet and by telephone. The survey collects data on ownership and acquisition of television sets and related receiving equipment. The error margin for the research results is estimated to be within 1-2 percentage points. Prior to Q1 2007 take-up figures also incorporated platform operator subscriber data.

\section{Postal Services (Table 9.5)}

Retail prices: In accordance with the Licence agreement, Royal Mail announces any retail price changes to be implemented in April before December 31st of the preceding year. The inflation figure that was factored into Royal Mail's price changes for April 2008 is the change in the Retail Price Index (RPI) for the reference period April 2007 to September 2007 and was $4.2 \%$.

Classification of first and second class mail: Royal Mail aims to deliver first class letters the next working day after collection, allowing customers to post their mail quickly and cheaply anywhere in the UK. Royal Mail aims to deliver second class letters by the third working day after collection, ideal for low priority correspondence. Delivery performance is monitored by a consumer watchdog.

Definitions:

'Volume of first class stamped mail delivered' and 'Volume of second class stamped mail delivered' relates to stamped mail only. 'Total first class mail delivered' and 'Total second class mail delivered' relates to stamped, metered, mailsort, standard tariff letter, Packetpost and Response Services products. 'Domestic parcels' refers to parcels delivered within the UK by Parcelforce Worldwide. 'International parcels' refers to parcels sorted by Parcelforce Worldwide that are delivered outside of the UK by overseas postal administrators and other international partners.

\section{METALS AND ENGINEERING}

\section{Iron and steel (Table 10.1)}

The general definition of the iron and steel industry is based on groups 221 'CSC Iron and Steel', 222 'Steel Tubes' and 223 'Steel Drawing, Cold Rolling and Cold Forming' of the UK Standard Industrial Classification (1980), except those parts of group 223 which cover the manufacture of drawn wire, wire products and cold formed sections.

The definition therefore covers blast furnaces and associated preparation plant, steel melting shops, ingot casting and continuous casting plant, hot rolling mills and cold wide strip or plate mills together with associated coating plants and tinplate mills. Also included are tube and pipe mills, cold narrow strip mills and bar drawing or cold finishing plants.

The definition also includes liquid steel for castings but excludes finished steel castings. Also excluded from the definition are refined iron, steel tyres, wheels, axles and rolled rings, open and closed die forgings, colliery arches, 
cold formed sections and finished wire. The definition also excludes the activities of iron foundries.

\section{Crude steel (Table 10.2)}

The total of usable ingots, usable continuously cast semifinished products and liquid steel for castings. This definition is identical to that of the ECSC and generally measures production of crude steel at the first stage of solidification, except that steel for castings is measured at the liquid stage since solidified castings do not fall within the scope of the ECSC Treaty of Paris.

\section{Alloy steel (Table 10.2)}

Steel containing by weight at least 0.5 per cent of silicon, or 1.6 per cent of manganese, or 0.3 per cent of chromium or nickel, or 0.0008 per cent of boron, or 0.1 per cent of any other element except carbon, lead, nitrogen, phosphorus or sulphur. Alloy steels include stainless steel and heat resisting steels which contain 10.5 per cent or more of chromium, with or without other alloy elements, and less than 1.2 per cent of carbon.

\section{Total Engineering (Table 10.4)}

The table shows non-seasonally adjusted current price total turnover data of the industries classified to Divisions 29, 30, 31, 32 and 33 of the Standard Industrial Classification 2003.

The estimates are based upon the results of monthly surveys and are also published on the National Statistics website.

\section{Mechanical, instrument and electrical engineering} (Tables 10.5 - 10.6)

These tables provide non-seasonally adjusted current price turnover estimates of total, home and export sales, orders-onhand and new orders (net of cancellations) of the industries classified to Divisions 29 and 30, of the Standard Industrial Classification 2003. The estimates for home sales and orderson-hand are obtained by subtracting exports from totals and estimates for new orders are derived from current sales and the change in orders-on-hand.

The non-seasonally adjusted estimates data for the total engineering industries are initially published monthly on the National Statistics website. The estimates are based upon the results of monthly inquiries.

\section{TEXTILES AND OTHER MANUFACTURES}

\section{Indices of production in the textile and clothing} industries (Table 11.1)

These indices provide a general measure of the changes in the volume of production in the textile and clothing industries. For further information regarding the compilation of these indices, see Section 7.

\section{UK manufacturers' sales by industry}

(Tables 11.2 - 11.5)

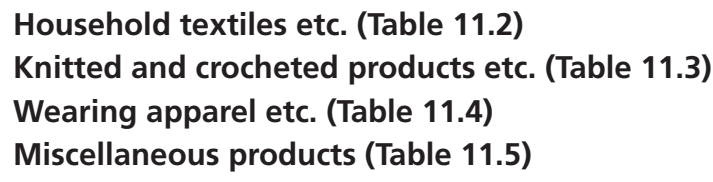

Household textiles etc. (Table 11.2)

Knitted and crocheted products etc. (Table 11.3)

Wearing apparel etc. (Table 11.4)

Miscellaneous products (Table 11.5)

The data in these tables are collected under the PRODCOM inquiry, which was introduced in 1993 and replaced the previous QSI/ASI inquiries. Data shown are monetary sales in $f$ thousand of products classified to the SIC 2003 industries that are surveyed annually by the PRODCOM inquiry. (They are a selection drawn from Table 22.2 of the Annual Abstract of Statistics). Detailed product sales data (values and quantities) together with exports and imports data are available in the Product Sales and Trade quarterly and annual reports (PRQ and PRA series). The quarterly series was terminated in 2005 and so quarterly backdated data is only available for periods up to the end of 2004. The annual series now incorporates the industries once covered by the quarterly series. Further information can be found on the National Statistics website www. statistics.gov.uk/Statbase/products. asp?vlnk=9660.

\section{CONSTRUCTION}

Value and volume of construction work and new orders obtained (Tables 12.1 - 12.2)

Figures for the construction industry are based on the 2003 Standard Industrial Classification.

The value of output represents the value of construction work done during the quarter in Great Britain and is derived from returns made by private contractors and public authorities with their own direct labour forces. The series (and the accompanying index of the volume of output) include estimates of the output of small firms and self-employed workers not collected in the regular quarterly output inquiry.

The new orders statistics are collected from private contractors and analysed by the principal types of construction work involved. The series includes speculative work for eventual 
sale or lease undertaken on the initiative of the respondent where no formal contract or order is involved.

\section{Building materials and components (Table 12.3)}

Unless otherwise stated, the figures are from returns submitted by producers.

\section{Building bricks}

The figures identify common, facing and engineering bricks made from clay, concrete or sandlime, but exclude both glazed bricks and all types of refractory bricks.

\section{Concrete building blocks}

Information refers to both dense and lightweight aggregate and to aerated concrete blocks.

\section{Concrete roofing tiles}

Figures refer to the area of roof covered.

\section{Ready-mixed concrete}

Figures are for production in the United Kingdom and are provided by the Quarry Products Association. They include production by members with an estimate for non-members.

\section{Slate}

The figures cover slate mined or quarried for all purposes including roofing and damp-proof courses, architectural and cladding uses.

\section{Sand and gravel}

The figures include both land-won and marine-dredged sales and identify building sand, concreting sand, gravel and hoggin.

\section{Housing (Table 12.4)}

The table on housebuilding relates to permanent dwellings built by private enterprise, registered social landlords (formerly Housing Associations) and local authorities. Temporary houses and mobile homes are excluded.

Figures for private enterprise and registered social landlords (excluding Scottish Homes) are each shown separately.

Figures for the public sector include houses provided by local authorities, Scottish Homes (formerly the Scottish Special Housing Association) and the Northern Ireland Housing Executive.
A dwelling is counted as started on the date work begins on the laying of foundations. A dwelling is regarded as completed when it becomes ready for occupation.

\section{TRANSPORT}

Road vehicles in Great Britain (Tables 13.1 - 13.2)

In general the classes of vehicles are based on the taxation classes set out in schedules to the Vehicle (Excise) Act 1971, although in certain cases they have been renamed. However, extensive reforms of vehicle taxation classes were introduced from 1 July 1995, involving the abolition of a number of little used tax classes, the creation of certain new classes and revisions to some existing classes.

\section{Private and light goods}

Includes all vehicles used privately, mostly consists of private cars and vans. From 1 October 1990 most goods vehicles less than 3,500 kgs gross weight were transferred into this group. Further vehicles previously taxed in other groups but not exceeding 3,500 kgs were transferred into this group from 1 July 1995, for example recovery tax class vehicles not over $3,500 \mathrm{kgs}$.

\section{Goods vehicles}

Mostly goods vehicles greater than 3,500 kgs gross vehicle weight but up to 1 July 1995 also included farmers' and showmen's goods vehicles some of which were less than $3,500 \mathrm{kgs}$. Separate goods categories for the use of showmen and farmers were abolished from 1 July 1995 and vehicles over 3,500 kgs revenue weight were absorbed into general goods tax classes one and two. Goods vehicles not exceeding 3,500 kgs were transferred into the private and light goods group. A special taxation class solely for the use of goods vehicles based and used on certain offshore islands was established.

\section{Public transport vehicles}

Vehicles used to convey members of the public were taxed as hackney vehicles up to 1 July 1995, including buses, coaches, taxis and private hire cars. The previous Hackney taxation class was abolished from 1 July 1995 and replaced by a new Bus class, for the taxation of vehicles used to convey members of the public for hire or reward. These are usually vehicles with nine or more seats. Buses and coaches not licensed for public use are taxed as private vehicles. Vehicles previously in the Hackney class but with eight seats or fewer were transferred to the private and light goods group. 


\section{Special concession group}

Until 1 July 1995 agricultural machines and other agricultural machinery were taxed at a special rate. This class also included works trucks, mobile cranes and mowing machines, vehicles making little use of public roads. This group was abolished from 1 July 1995, and replaced by a group termed 'special concessionary'. This continues to include agricultural machines, but was extended to include snowploughs, gritting vehicles, and electric vehicles among others. However, some heavy vehicles previously in the agricultural and special machines group were transferred to the 'special vehicles' group described above.

\section{Special vehicles}

A group established from 1 July 1995 and used primarily for the taxation of heavy vehicles, but where taxation as a standard goods vehicle would not be appropriate. Examples include showmen's haulage vehicles, mobile cranes, digging machines, road rollers, etc.

\section{Exempt vehicles}

Exempt vehicles pay no excise duty. Exempt vehicles are divided into two further groups, those which are registered but carry no licence, and those which renew their licence annually but pay a nil rate of duty. Vehicles owned by government departments and operating under certificates of crown ownership pay no tax under the Vehicle (Excise) Act and are termed 'Crown' vehicles, falling into the first of these categories.

Among vehicles exempt from tax, a group covering emergency vehicles was created from 1 July 1995 . This group includes ambulances, fire engines, other fire service vehicles, life boat haulage, mine rescue and police vehicles. Some changes were made to the list of exempt vehicle types. For example, electric vehicles, previously exempt, were moved to the special concessionary group.

A new tax class was introduced from 29 November 1995 for vehicles previously in private or light goods or motorcycle classes and over 25 years of age which are now exempt from duty.

\section{Sources}

Statistics are based on licensing records held at the Driver and Vehicle Licensing Agency (DVLA) at Swansea. Before 1978, however, statistics of vehicles currently licensed were based on a combination of those records which were held at DVLA and those which were held at local taxation offices. Pre-1978 figures have been adjusted to be comparable with later figures based wholly on DVLA records.

\section{Road traffic and goods transport in Great Britain (Table 13.3)}

The index of tonne-kilometres of road goods transport is estimated from the Continuing Survey of Road Goods Transport. Quarterly index numbers for road transport are obtained by dividing each quarter's figure of tonne-kilometres performed by road by the quarterly average in 1977 . The quarterly figures relate to 13 -week periods and not to three calendar months, so no adjustment for differences in the length of calendar months is necessary. Annual index numbers are obtained in a similar way by dividing the estimated annual road tonne-kilometres by the corresponding figure in 1977.

The index of vehicle kilometres travelled on roads in Great Britain is estimated from roadside traffic counts which take two forms: occasional short counts at large numbers of sites to estimate the absolute level of traffic (the DfT manual counts) and continuous automatic counts at a small number of sites (the DfT automatic counts) to estimate changes in the amount of traffic. These counts are used to derive average vehicle flow and the vehicle kilometre estimates are the product of this average flow and the total lengths of roads.

\section{Road casualties in Great Britain (Table 13.4)}

These figures are compiled from information received by the Department for Transport, the Scottish Executive and the National Assembly for Wales from police forces throughout Great Britain. Only those casualties in road accidents occurring on the public highway (including footways), in which a road vehicle was involved, and which became known to the police within 30 days of the accident are included.

Casualties are classified according to the degree of injury sustained. The degrees of injury are defined as follows:

Killed: a person who sustained injuries which caused death less than 30 days after the accident.

Seriously injured: a person detained in hospital as an 'inpatient', or any of the following injuries whether or not they are detained in hospital: fractures, concussion, internal injuries, crushings, severe cuts and lacerations, severe general shock requiring medical treatment, and injuries causing death 30 or more days after the accident.

Slightly injured: a person sustaining an injury of a minor character such as a sprain, bruise, or cut which are not judged to be severe, and do not necessarily require medical attention; or slight shock, requiring roadside attention. 


\section{Road passenger transport (Tables 13.5 - 13.6)}

The figures are derived from the annual returns of bus and coach operators. A passenger journey is defined as each single boarding of a vehicle.

\section{Indices of local (stage) bus fares}

The information used to calculate the index of local (stage) bus fares is collected from a panel of the larger PSV operators accounting for over 85 per cent of passenger receipts from local services in Great Britain.

\section{Passenger journeys (Table 13.7)}

On London Underground all journey figures are for complete journeys, which may include more than one stage. Return tickets are counted as two journeys. Season ticket journeys are those estimated to have been made in each year irrespective of when the ticket was sold.

\section{Passenger traffic (Table 13.7)}

\section{National Rail}

\section{Methodology for passenger journeys}

The rail industry's central ticketing system, LENNON, is the basis for passenger journeys and kilometres data. LENNON holds information on all national rail tickets purchased in Great Britain and is used to allocate the revenue from ticket sales between Train Operating Companies (TOCS). LENNON, however does not correctly record sales of certain products, in particular some operator-specific tickets and Passenger Transport Executive (PTE) multi-modal tickets. The journeys from this tickets are added in at the end of the each financial year when a reconciliation exercise with the TOCs takes place.

\section{Journeys datasets in LENNON}

LENNON contains two datasets - pre-allocation (sales) and post-allocation (earnings). Passenger usage statistics in National rail trends are based on the post-allocation dataset. Allocations are created for each ticket group, dependant on sales levels, by ORCATS (Operational Research Computer Allocation of Tickets to Services). These allocations are principally used to apportion journeys between TOCs.

ORCATS is a mathematical model, introduced in the 1980s, which uses a similar logic to journey planning systems and identifies passenger 'opportunities to travel' from an origin station to a destination station using timetable information. An opportunity to travel may include one or more changes of train, and one journey will be generated for each train used during an opportunity to travel. This will result in the number of journeys being inflated by around 5\%, compared to the pre-allocation dataset which does not assign journeys between TOCs.

The data do not include the non-franchised Train Operating Companies (TOCs).

\section{Freight traffic (Table 13.8)}

Freight moved is measured in net tonne kilometres (NTKm). This takes into account the net weight (excluding the weight of the locomotive and wagons) of the goods carried (the freight lifted, measured in tonnes) and the distance carried.

Freight lifted is the mass of goods carried on the network. It excludes the weight of the locomotives and wagons. Unlike freight moved it takes no account of the distance travelled.

The figures include all revenue-earning traffic carried on freight trains in Great Britain. They include traffic carried by English, Welsh and Scottish Railways (EWS), Freightliner, Direct Rail Services (DRS) and GB Railfreight.

\section{Civil aviation (Table 13.9)}

The statistics cover the scheduled services of major UK airlines.

Scheduled services are services performed for remuneration according to a published timetable and which are open to use by members of the public. Extra revenue flights occasioned by overflow traffic from scheduled flights are also included.

The figures refer only to revenue kilometres and traffic and therefore exclude such items as training, positioning and test flights and non-revenue passengers and cargo.

In combining kilometre statistics, distances have been calculated on the great circle distance between two traffic stops. If a technical stop intervenes the distance is the sum of the two stages caused by the technical stop.

\section{International services}

Services flown between the United Kingdom, Isle of Man, Channel Islands and points overseas, and services flown between points outside the United Kingdom, Isle of Man and Channel Islands.

\section{Aircraft kilometres}

Figures are calculated by multiplying the number of flights performed by the stage distance. 


\section{Passengers uplifted}

A passenger for whose transportation an air carrier receives commercial remuneration. The figures are calculated by counting each revenue passenger on a particular flight (with one flight number) once only and not repeatedly on each individual stage of that flight. Exclusions: a) persons travelling free; b) persons travelling at a fare or discount available only to employees of air carriers or their agents or only for travel on business for the carriers; c) infants who do not occupy a seat.

\section{Seat kilometres used}

The figures are calculated by multiplying the number of revenue passengers carried on each stage flight by the stage distance.

\section{Cargo}

The weight of property carried on an aircraft including, for example, the weight of freight, mail, excess baggage and diplomatic bags, but excluding passengers' and crews' permitted baggage.

\section{Freight (or mail) tonne kilometres used.}

The figures are calculated by multiplying the number of tonnes of freight and diplomatic bags carried on each stage flight by the stage distance. Mail tonne kilometres are calculated in a similar way.

\section{Passenger tonne kilometres used}

These are calculated by multiplying the weight of passengers carried on each stage flight by the stage distance.

\section{Shipping (Table 13.10)}

\section{Merchant vessels registered in the United Kingdom}

Trading vessels of 500 gross tonnage and over registered within the United Kingdom, the Channel Islands and the Isle of Man.

\section{Bulk tanker and dry}

The following ship types are included:

Oil tankers, oil chemical tanker, chemical tanker, liquefied gas carriers, and other specialised tankers; and dry bulk carriers including bulk carriers and bulk-oil carriers.

\section{Other}

The following ship types are included:

General cargo roll-on/roll-off and lift-on/lift-off vessels, fully cellular container and part containerised ships, other specialised dry cargo vessels, cruise liners and other passenger carrying vessels.

\section{Non-trading vessels}

The following vessel types are excluded:

Sailing ships, offshore supply and support vessels, special service, tugs, fishing, research, dredgers/hoppers/barges, and naval auxiliary vessels.

\section{Gross tonnage}

Gross tonnage is the total volume of all the enclosed spaces of a vessel. Under the International Convention on the Tonnage Measurement of Ships, 1969, gross tonnage (GT) is defined as the following function of the total volume of all enclosed spaces in the ship $(V)$, in cubic metres:

$$
\begin{aligned}
& \mathrm{GT}=\mathrm{K} 1 \mathrm{~V} \\
& \text { where } \mathrm{K} 1=0.2+0.02 \log 10 \mathrm{~V} .
\end{aligned}
$$

Although the convention is fully in force, the old 'gross registered tons' measure may still be the measure recorded on Lloyd's Register-Fairplay World Fleet Database in a small proportion of cases. This was directly related to the capacity of the space within the hull, and of the enclosed spaces above the deck, which were available for cargo, stores, passengers and crew, with certain exceptions. In practice, old and new tonnage measures are fairly similar, except for ships with substantial exempt spaces under the old system, such as RORO vessels.

\section{Dead-weight tonnage}

Deadweight tonnage (dwt) is the total maximum weight in tonnes that a ship can legally carry, that is, the total weight of cargo, bunkers, fuel, stores and crew. Statistics are compiled in metric units (one deadweight ton (imperial) $=1.016$ deadweight tonnes).

\section{UK passenger movement (Tables 13.11 - 13.12)}

\section{Sea and cruise passengers}

The tables contain international short-sea ferry passenger movements at UK ports (i.e. sailings between the UK and Belgium, Denmark, Faroe Isles, Finland, France, Germany, Ireland, Netherlands, Norway, Spain and Sweden) and 
international cruise or scheduled long sea voyage passengers embarking or disembarking at UK ports. Drivers of vehicles are included in the ferry passenger numbers.

Further information on sea and waterborne passengers is published in Chapters 3 and 4 of DfT's annual Maritime Statistics reports.

\section{RETAILING}

\section{Retail sales (Tables 14.1 - 14.2)}

The monthly retail sales estimates cover the retail trades (excluding the motor trades) in Great Britain.

The inquiry provides soundly based estimates as it covers all large retailers and a random sample of smaller retailers. The sample size is approximately 5,000. The use of statutory powers means that it has been possible to improve the sample design at the detailed level and reduce the sampling error associated with the results.

For each four or five week period, contributors report their retail sales for all their outlets, internet sites and by mail order catalogue. The statistics include VAT. Hire purchase and other instalment credit sales are valued at the credit price of the goods; that is including deposits and, where credit is provided by the shop, credit charges. Figures of credit sales relate only to the period during which the transactions took place; cash received from credit sales in previous periods is not included. Sales by chemists exclude receipts under the National Health Service. The sale of mobile phones and their accessories are included but contracts and airtime vouchers are excluded.

The retail sales index is based on the results of the 2000 annual business inquiry. From October 2003, the monthly retail index was rebased using detailed information from the larger scale 2000 annual business inquiry.

The main features of the series are:

- $\quad$ The reference year has been set at $2000=100$.

- It incorporates price deflators for each SIC (92) class based on the pattern of trade shown by the 2000 annual business inquiry. These deflators are used to convert the value estimates on to a constant price or volume basis: most components of the retail sales index are deflated onto a volume basis using price data from the retail prices index.

- The index is now calculated using ratios estimation.
- The seasonal adjustment factors reappraised annually to ensure they reflect the seasonal pattern.

The latest summary statistics are published each month by First Release; more disaggregate value indices (not seasonally adjusted) are published each month in the ONS Business Monitor SDM 28: Retail Sales via the National Statistics website www.statistics.gov.uk/rsi. Retail Sales information may also be obtained by contacting Retail Sales Branch, ONS, Room A012, Government Buildings, Cardiff Road, Newport, NP10 8XG. Tel: 01633 455602. Alternatively e-mail retail.sales. enquiries@ons.gov.uk

\section{EXTERNAL TRADE IN GOODS}

Statistics of the United Kingdom's overseas trade in goods are compiled by the Office for National Statistics from information provided to HM Revenue and Customs by importers and exporters. A detailed description of the bases on which the statistics are compiled and the methodologies used is contained in a paper entitled 'Statistics on Trade in Goods'. This paper, which is Number 36 in the GSS Methodological Series, is available on the National Statistics website at http://www.statistics.gov.uk/Statbase/Product.asp?vlnk=14943

\section{Figures excluding oil and the more erratic items (Tables 15.1 - 15.2)}

Tables 15.1 and 15.2 show figures for trade excluding oil and the more erratic items. Oil means SITC Division 33 (petroleum and petroleum products). Experience suggests that trade in ships, aircraft, precious stones and silver can be regarded as erratic. Precious stones are classified to SITC Division 66 (non-metallic mineral manufactures), silver to Division 68 (non-ferrous metals) and the other erratic items to Division 79 (other transport equipment).

\section{Balance of Payments (BoP) Data (Tables 15.1 - 15.9)}

The information included in Tables 15.1 to 15.9 inclusive is on a BoP basis with exports and imports both valued 'fob' (free on board), i.e. excluding insurance premiums and freight. For a complete description of the procedures undertaken to convert data from an OTS basis to a BoP basis, see 'Statistics on Trade in Goods' referred to above.

\section{Commodity classification (Tables 15.3 - 15.7)}

Statistics of trade in goods are classified by commodity according to the Standard International Trade Classification (SITC Rev3), apart from defence equipment which is included in Section 9 rather than Section 8. Useful references are SITC revision 3, published in 1986 by the United Nations, and the 
HMRC's annual Guide to the Classification for Overseas Trade Statistics published as Business Monitor OTSG.

\section{Price and volume indices (Tables 15.4 - 15.5)}

The indicators of price movement 'deflators' for individual commodities used in the calculation of price and volume indices are based in part on separately collected export and import price indices. Use is also made of adjusted producer price indices for exports and imports of manufactures. For other commodities where export and import price indices do not exist the price indices are based on the value and quantity data reported to Customs. For data prior to 1995 the calculation of price and volume indices is still based mainly on Customs data. A more detailed description of the deflation system can be found in 'Statistics on Trade in Goods' - see above

\section{Definition of areas (Tables 15.8 - 15.9)}

As at 2008 the areas shown in Tables 15.8 and 15.9 comprised the following countries.

- Western Europe excluding the EU - Norway, Iceland, Switzerland, Andorra, San Marino, Vatican City, Turkey, Faroe Islands, Gibraltar, Liechtenstein;

- $\quad$ North America - United States of America, Canada, Greenland, Mexico, St. Pierre \& Miquelon, Puerto Rico;

- $\quad$ Other OECD countries - Japan, Australia, New Zealand, Ceuta and Melilla, South Korea;

- $\quad$ Oil exporting countries - Abu Dhabi, Algeria, Bahrain, Brunei, Dubai, East Timor, Ecuador, Gabon, Indonesia, Iran, Iraq, Kuwait, Libya, Nigeria, Oman, Qatar, Saudi Arabia, Sharjah etc, Trinidad \& Tobago, Venezuela;

\section{Further Information (Tables 15.1 - 15.9)}

More detailed figures on a BoP basis are shown in the Monthly Review of External Trade Statistics, as Business Monitor MM24. Editions of MM24 are available in electronic format and made as Adobe downloadable portable document formats (PDFs) on the National Statistics website (www.statistics. gov.uk/bop). The PDF files are available free of charge. OTS figures, not seasonally adjusted, appear in Overseas Trade Statistics of the United Kingdom, published monthly by The Stationery Office as OTS1, which also contains further information about definition and coverage of data. From January 1993 this publication relates only to non-EU trade. There are two publications showing EU trade. The first OTS2 being a monthly summary showing data by country and by broad commodity group (SITC division), and the second OTSQ providing quarterly detailed commodity level tables. Once published the figures are still subject to revision as late returns are processed and revisions are reflected in year-to-date figures. The annual publication OTSA combines the intra-EU and non-EU data.

Unadjusted OTS figures are also available from marketing agents appointed by HM Revenue and Customs or on HMRC's website at http://www.uktradeinfo.com

\section{UK BALANCE OF PAYMENTS}

\section{Balance of payments (Tables 16.1 - 16.3)}

The items in these tables are more fully described in United Kingdom Balance of Payments 2008 edition - the ONS Pink Book.

\section{Summary of Balance of Payments (Table 16.1)}

The Balance of Payments consists of the current account, the capital account and the financial account. The current account consists of trade in goods and services, income and current transfers. Income consists of investment income and compensation of employees. The capital account mainly consists of capital transfers and the financial account covers financial transactions. Every credit entry in the balance of payments accounts should, in theory, be matched by corresponding debit entry so that total current capital and financial account credits should be equal to, and therefore offset by, total debits. In practice there is a discrepancy termed net errors and omissions.

\section{The current account (Table 16.2)}

\section{Trade in goods}

The goods account covers exports and imports of goods. Imports of motor cars from Japan, for example, are recorded as debits in the trade in goods account whereas exports of vehicles manufactured in the UK are recorded as credits. Trade in goods forms a component of the expenditure measure of Gross Domestic Product (GDP).

\section{Trade in services}

The services account covers exports and imports of services (e.g. civil aviation). Passenger tickets for travel on UK aircraft sold abroad, for example, are recorded as credits in the services account whereas the purchases of airline tickets from foreign airlines by UK passengers are recorded as debits. Trade 
in services, along with trade in goods, forms a component of the expenditure measure of Gross Domestic Product (GDP).

\section{Income}

The income account consists of compensation of employees and investment income and is dominated by the latter. Compensation of employees covers employment income from cross-border and seasonal workers which is less significant in the UK than in other countries. Investment income covers earnings (e.g. profits, dividends and interest payments and receipts) arising from foreign investment and financial assets and liabilities. For example, earnings on foreign bonds and shares held by financial institutions based in the UK are recorded as credits in the investment income account, whereas earnings on UK company securities held abroad are recorded as investment income debits. Investment income forms a component of Gross National Income (GNI) but not Gross Domestic Product (GDP).

\section{Current transfers}

Current transfers are composed of general government transfers (e.g. taxes and payments to and receipts from the European Union) and other transfers (e.g. gifts in cash or kind received by private individuals from abroad or receipts from the EU where the UK government acts as an agent for the ultimate beneficiary of the transfer). Current transfers do not form a component either of Gross Domestic Product (GDP) or of Gross National Income (GNI). For example payments to the UK farming industry under the EU Agricultural Guarantee Fund are recorded as credits in the current transfers account while payments of EU agricultural levies by the UK farming industry are recorded as debits in the current transfers account.

\section{Financial account (Table 16.3)}

While investment income covers earnings arising from foreign investments and financial assets and liabilities, the financial account of the balance of payments covers the flows of such investments. While earnings on foreign bonds and shares held by financial institutions based in the UK are, for example, recorded as credits in the investment income account, the acquisition of such foreign securities by UK based financial institutions are recorded as net debits in the financial account as portfolio investment abroad. Similarly the acquisitions of UK company securities held by foreign residents are recorded in the financial account as net credits as portfolio investment in the UK.

\section{GOVERNMENT FINANCE}

\section{Public sector finances (Table 17.1)}

Table 17.1 shows information on all the key public sector finance statistics. The government 's key fiscal indicators have been given far greater prominence, reflecting more closely the structure of the public sector finances and public sector accounts first releases. The statistics are used to monitor progress against the government's key fiscal rules, the 'golden rule' and the sustainable investment rule.

\section{Central government transactions and fiscal balances (Table 17.2)}

Table 17.2 shows details of the income and expenditure determinants of central government net borrowing and the surplus on current budget.

Taxes on production. This series includes Value added tax, tax on tobacco, hydrocarbon oils, stamp duties, National non-domestic rates and various other taxes. The biggest component, VAT, is also shown separately.

Taxes on income. Included here are taxes on income and taxes paid by corporations. This includes Capital Taxes Series.

Other taxes. Included in this series are motor vehicle taxes paid by households and inheritance tax.

Compulsory social contributions. These are National Insurance Contributions.

Interest and dividends. These are receipts of interest and dividends to central government.

Other receipts. These include rent and other current transfers, including oil royalties and the 3rd generation mobile phone spectrum net receipts.

Interest. This is interest paid by central government to the private sector and the rest of the world.

Net social benefits. Includes Social security benefits and other benefits paid to households by central government.

Other current expenditure. This includes current expenditure on goods and services, subsidies, current grants within general government and some other current transfers.

Gross saving is derived by subtracting total current expenditure from total current receipts, the surplus on current budget is then derived by taking account of depreciation. 


\section{Public sector aggregates (not seasonally adjusted) (Table 17.3)}

Table 17.3 show the key public sector balances drawn from national accounts, plus the public sector net cash requirement.

\section{The surplus on current budget}

This is net saving plus capital taxes (B8n+D91 uses from national accounts). The surplus on current budget represents the balance of revenue over current expenditure, whereas net borrowing (see below) measures the overall budget deficit, i.e. the balance of receipts over expenditure, both current and capital. This fiscal balance measures achievement against the Golden Rule, which states that over an economic cycle government should only borrow to finance investment. The surplus on current budget therefore represents the surplus available for investment.

\section{Net borrowing}

(B9 from the national accounts). Net borrowing is a concept based on internationally agreed definitions. Net borrowing measures the change in the public sector's accruing net financial indebtedness. Net borrowing is an accruals concept, whereas the closely related net cash requirement is almost entirely a cash measure.

More information on the concepts in tables 17.1, 17.2 and 17.3 can be found in a guide to monthly public sector finance statistics, GSS Methodology Series No 12, the ONS First Releases Public Sector Finances and Public Sector Accounts and Financial Statistics Explanatory Handbook

\section{Selected financial statistics (Table 17.4)}

This table shows a selection of financial statistics. Further details are to be found in Financial Statistics.

\section{Money stock and liquidity (Table 17.5)}

There is no single, universally accepted, definition of money. Any single definition must be, to some extent, arbitrary: a range of monetary aggregates is therefore produced reflecting different bands on the spectrum of liquidity.

The current definitions of the monetary aggregates $\mathrm{M} 0, \mathrm{M} 2$ and M4 are detailed below, M3 formerly known as fM3, ceased to be published (along with M1 and M3c) from July 1989 following Abbey National Building Society's conversion to a public limited company (see Bank of England Quarterly Bulletin August 1989). NIBM1 (a measure of transactions money) ceased to be published in November 1990. M2 ceased to be published from December 1992 following the redefinition of deposits which, along with notes and coins, comprise M2.
MO comprises notes and coins in circulation outside the Bank of England plus bankers' operational balances with the Bank. For the major components of $\mathrm{MO}$, the level for each month is the average of the levels on all the Wednesdays of that month, and the change is the difference between those average levels (adjusted for any breaks in series).

M4 is made up of notes and coins in circulation with the public, together with all deposits (including certificates of deposit and other short-term paper) with banks and building societies denominated in sterling and held by the UK private sector (other than banks and building societies).

For further details see the Bank of England Quarterly Bulletin March 1981, June 1982, December 1982, March 1983, March 1984, May 1987 and August 1990. A fuller analysis of the figures is shown in Financial Statistics and in the Bank of England Quarterly Bulletin.

Details of breaks in monetary series are described in Technical Series paper No 23 entitled 'Breaks in Monetary Series' published by the Bank of England Statistical Abstract, Part 2' issued in November 1993. The definitions of the monetary aggregates were considered in a Discussion paper issued by the Bank in March 1990; responses to the paper, and the Bank's reaction to the responses were described in the August 1990 bank of England Quarterly Bulletin, pages 336-37.

In the seasonally adjusted data, the adjustments are generally constrained to sum to zero over the financial year for the monthly and quarterly monetary aggregates and over the calendar year for sectoral data. (For further information on seasonal adjustments see page 30 of United Kingdom Flow of Funds Accounts: 1963-1976, published by the Bank of England in May 1978, the Bank of England Quarterly Bulletin June 1983, December 1986, February 1989, February 1991, August 1991 and February 1992).

Selected interest rates, exchange rates and security prices. Details of the series can be found in chapter 7 of Financial Statistics.

\section{PRICES AND WAGES}

\section{Consumer Prices Index (CPI) (Tables 18.1 - 18.2)}

The Consumer Prices Index is the main United Kingdom domestic measure of inflation for macroeconomic purposes. Like the RPI (see below) it measures the average change from month to month in the prices of consumer goods and services purchased in the UK, but there are differences in coverage and methodology. A detailed description of these differences is given in the paper entitled "The New Inflation Target: the 
Statistical Perspective". This paper is available on the National Statistics website: http://www.statistics.gov.uk/StatBase/ Product.asp?vlnk=10913. Since 10 December 2003, the Government inflation target for the UK has been based on the CPI measure of inflation. Prior to that the CPI had been published in the UK as the harmonised index of consumer prices (HICP); the two remain one and the same index. For further information on HICPs see below.

CPI inflation rates prior to 1997 and index levels prior to 1996 are estimated. See article on National Statistics website: http:// www.statistics.gov.uk/cci/article.asp?|D=31. Also the coverage of CPI categories for health, education and miscellaneous goods and services have been extended between 2000 and 2002. Details are given in articles available on the National Statistics website: http://www.statistics.gov.uk/cci/searchres2. asp?ct=6\&term $=\mathrm{HICP}$

Further details on the CPI are available from National Statistics website: www.statistics.gov.uk/cpi

\section{Retail Prices Index (RPI) (Tables 18.3 - 18.5)}

The Retail Prices Index is the more familiar general purpose measure of inflation in the UK, measuring the percentage changes month by month in the average level of prices of the goods and services purchased by the great majority of households in the United Kingdom. The uses of the RPI include indexation of pensions, state benefits and index-linked gilts.

The weights used for combining the indices for the various groups of items are revised annually on the basis of information from the Expenditure and Food Survey (EFS), for (generally) the year ended in the previous June. Further details on the EFS and the annual Family Spending reports are available from the National Statistics website: http://www. statistics.gov.uk/statbase/Product.asp?vlnk=361

The index is calculated monthly in respect of a Tuesday near the middle of each month.

Expenditure covered by the index does not include:

- $\quad$ income tax payments

- national insurance contributions

- $\quad$ savings or investments (e.g. pension contributions and the capital element of mortgage payments for house purchase)

- $\quad$ gifts and donations which are not made in return for any specific service (e.g. church collections)
- $\quad$ expenditure for which no 'unit of purchase' can be identified for purposes of price collection (e.g. on betting)

For expenditure coming within the scope of the index a representative list of items has been selected and the prices of these items are collected each month. Quotations are obtained from shops and other outlets typical of those used by the majority of households, in around 150 areas throughout the United Kingdom. The prices used are the prices actually charged. So far as possible they relate to goods of unchanged quality at successive dates.

Further details on the RPI are available from the National Statistics website: www.statistics.gov.uk/rpi

\section{Harmonised indices of consumer prices (HICPs) (Table 18.6)}

This is calculated in each Member State of the European Union (EU), according to rules specified in a series of European Regulations developed by the EU statistical office in conjunction with the EU Member States. The HICPs are used to compare inflation rate across the EU. Since January 1999 it has also been used by the European Central Bank (ECB) as the measure of price stability across the Euro area.

More information on HICPs is available from the National Statistics website: www.statistics.gov.uk/hicp

\section{Purchasing power of the pound (Table 18.7)}

Changes in the internal purchasing power of a currency may be defined as the 'inverse' of changes in the levels of prices; when prices go up, the amount which can be purchased with a given sum of money goes down. From January 1962 onwards, movements in the internal purchasing power of the pound are based on the Retail Prices Index (RPI). The RPI is preferred to other sources (such as the Consumer Price Index) as it has a much longer history and therefore a more comprehensive time series of data exists to compare the purchasing power of the pound.

It should be noted when making comparisons that the figures relate to national averages therefore they are not necessarily valid for any particular group or region. Also, because of continual changes in the pattern of household expenditure, comparisons over longer periods can only be regarded as approximate. If the purchasing power of the pound is taken to be 100p in a particular year, the comparable purchasing power in a subsequent year is:

$100 \times \frac{\text { average price index for earlier year }}{\text { average price index for later year }}$ 


\section{Tax and price index (Table 18.8)}

The purpose and methodology of the Tax and Price Index (TPI) were described in an article in the August 1979 issue (No 310) of Economic Trends (HMSO 1979). The purpose is to produce a single index which measures changes in both direct taxes (including national insurance contributions and tax credits, the latter of which is treated as negative taxation) and in retail prices for a representative cross-section of taxpayers. Thus, while the Retail Prices Index may be used to measure changes in the purchasing power of after-tax income (and of the income of non-taxpayers) the Tax and Price Index takes account of the fact that taxpayers will have more or less to spend according to changes in direct taxation. The index measures the change in gross taxable income which would maintain their after-tax income in real terms. Further information on the TPI can be found in Chapter 10.6 of the CPI Technical Manual which is available on the National Statistics website: http://www.statistics.gov.uk/downloads/ theme economy/CPI Technical_Manual.pdf

\section{Index numbers of producer prices (PPI) (Table 18.9)}

There are two broad groups of Producer Price Indices; output prices and input prices. Output prices are the prices of goods produced by the manufacturers and sold to the home market. Input prices are the prices of materials and fuels purchased by manufacturers in order to produce their goods.

The Producer Price Indices are calculated from the price movements of around 6,750 closely defined products. It is a base weighted index working on the basket of goods concept. A wide range of representative products are selected and the prices of these goods collected each month. The movement in these prices are weighted to reflect the relative importance of the products in a chosen year (known as the base year) currently 2005. This price data is converted into a basic set of price indices from which broad series are built up. Output prices (products destined for sale in the UK) are grouped in accordance with the Standard Industrial Classification 1992 with weighting patterns based on overall sales by manufacturers within those groupings. Input prices are grouped in accordance with Input/Output table groupings. The indices published in this monitor are widely used by business in price escalation clauses in contracts and for monitoring price movements in the products they trade.

The high level index numbers shown in Table 18.9 are constructed on a net sector basis - i.e. the index for any sector relates only to transactions between that sector and other sectors, within-sector sales and purchases are excluded. For example, the index for materials and fuel purchased by manufacturing industry is designed to reflect only changes in the prices of purchases that manufacturing industry taken as a whole obtained from the UK non-manufacturing sector and from abroad, it does not reflect changes in the prices of purchases from within the UK manufacturing sector. The index numbers for selected industries in Table 18.9 are constructed on a gross sector basis i.e. all transactions are included in deriving the weighting patterns, including sales within the same industry.

The indices relate to average prices for a month. The full effect of a price change occurring part-way through any one month will only be reflected in the index for the following month. The index numbers are compiled exclusive of VAT. Excise duties (on cigarettes, manufactured tobacco, petroleum and alcoholic liquor) are included.

\section{Construction output price index (column JYYC in Table 18.9)}

The index relates to quarterly changes in the price actually being paid for new building and civil engineering work being carried out at the time in Great Britain, excluding repair and maintenance. It is a weighted combination of the separate tender price indices for contractors' output in six work sectors, for several previous quarters up to the quarter to which the index refers. A description of the methodology of the indices is given in the Construction Statistics Annual 2008 (Appendix 2).

\section{Monthly house price index of all dwellings, by re- gion (Table 18.10, series FCBA in Table 18.9)}

Information on dwelling prices at national and regional levels are collected and published by Communities and Local Government (CLG) on a monthly basis from a survey of mortgage completions, the Regulated Mortgage Survey (RMS) which replaced the Survey of Mortgage Lenders (SML) in 2005. The Survey covers banks and building societies, who supply data to the Council of Mortgage Lenders (CML).

Data prior to 2002 Q1 were derived from a 5\% sample of completions data and were calculated on an old mix-adjusted methodology. As a consequence of a significantly increased sample the CLG were able to introduce a new monthly series. The mix-adjusted methodology was also enhanced. The monthly series are available back to February 2002. The quarterly series from 2002 Q2 have also been revised to reflect the monthly house price figures, and the quarterly and annual series were rebased to 2002 Q1. The CLG currently receive about $60 \%$ of all mortgage completions from the Regulated Mortgage Survey.

Series FCBA provides a monthly, quarterly and annual mixadjusted index for the average price of new dwellings at mortgage completion stage for the UK. Note that the index should be treated with caution as there are relatively small 
numbers of new dwellings, and prices of new homes tend to be more volatile than for existing homes, often because of variations in the additional features that are included in some new developments but not in others.

The indices in Table 18.10 are based on the mix-adjusted index average prices of all dwellings at mortgage completion stage by Government Office Region. The series are not seasonally adjusted.

Prices are based on completions (rather than mortgage approvals) which relate to dwellings actually purchased. A small but significant number of mortgage approvals do not result in completed transactions.

Why and how is the index "mix-adjusted" ? If the index were based on changes in the simple average price, the movements of the index would be influenced by changes in the mix of properties bought in each period. This effect is removed by applying fixed weights at the start of each year, based on the average mix of properties purchased during the previous three years.

The mix-adjusted indices exclude sitting tenant ("right-tobuy") purchases, cash purchases remortgages and further loans.

Further mix-adjusted average prices and indices are available on the CLG website, within the House Price Index section (www.communities.gov.uk/housepriceindex).

\section{Indices of producer prices of agricultural products and of purchase prices of the means of agricultural production (Table 18.11)}

The monthly and annual index numbers of agricultural prices in the United Kingdom cover all the main agricultural products and also the main groups of materials currently consumed by agriculture. The indices are currently based on the calendar year 2000. They are designed to provide short-term and medium-term indications of movements in these prices. All annual series are base-weighted Laspeyres type, using value weights derived from the Economic Accounts for agriculture 2000 prepared for the Statistical office of the European Union. Monthly indices for some purchase prices and non-seasonal product prices are calculated using annual weights and base prices which are weighted means of the 2000 monthly prices. Monthly indices for seasonal product prices and the following purchase prices; Seeds, Energy \& Lubricants, Fertilisers and Animal Feedstuffs are calculated using a monthly weight which is the annual weight of the product distributed over its trading months. The base prices used are weighted of the 2000 monthly prices. Prices are measured exclusive of VAT. For practical reasons, it has generally been necessary to measure the prices received by producers (outputs) at the first marketing stage and prices of materials (inputs) ex-supplier.

The construction of the indices enables them to be combined with similar indices for other member countries of the European Union to provide an overall indication of price trends within the Union which appears in the Union's Eurostat series of publications.

Index numbers at a more detailed level and for earlier based series are available from the Department for Environment, Food and Rural Affairs, Zone A2 Third Floor, Foss House, King's Pool 1-2 Peasholme Green, York, YO1 7PX. Tel: 01904 455249.

\section{Average weekly earnings and hours worked in manufacturing and certain other industries (Tables 18.12 - 18.14)}

The Annual Survey of Hours and Earnings (ASHE) covers 0.8 per cent sample of employees in employment in all sectors of the United Kingdom economy. Information is collected from employers on the earnings and hours of individual employees in the pay-period containing a particular date in April each year.

The earnings figures relate to gross pay before tax, National Insurance or other deductions, and exclude payments in kind. They are restricted to earnings relating to the survey pay period, and so exclude payments of arrears from another period (any payments due as a result of a pay settlement but not yet paid will also be excluded). Changes in average earnings between successive surveys represent the combined effect of a number of factors, including: (a) pay settlements implemented between the April survey dates (the changes in average earnings for particular groups of employees may be affected by changes in the timing of settlement); (b) variations in the amount of overtime and other payments relative to basic pay; and (c) changes in the proportions of employees in different occupations and industries.

The survey sample is largely drawn from records of those who are members of Pay As You Earn (PAYE) schemes, and so its coverage of people with very low weekly earnings - mostly part-time employees - is incomplete. Most published results are confined to full-time employees on adult rates whose earnings for the survey pay-period were not affected by absence.

The ASHE survey provides a wealth of detailed information on the levels, distribution and make-up of earnings in the United Kingdom. The results of the survey are on the Office for National Statistics website http://www.statistics.gov.uk/ StatBase/Product.asp?vlnk=13101 
Index of average earnings of all employees (AEI) (monthly inquiry) (Tables 18.15 - 18.16)

The Average Earnings Index (AEI) is designed to measure changes in the level of earnings i.e. wage inflation in Great Britain. Average earnings are calculated as the total wages and salaries paid by firms, divided by the number of employees paid. Like all indices, changes are measured against a base year, whose index value is set to 100 . The current base year is 2000 for both tables 18.15 and 18.16.

Indices are given for 20 industry groups of the Standard Industrial Classification 1992, all manufacturing industries, production industries, all service industries, public and private sectors and the whole economy. For the last six indices, actual and seasonally adjusted figures are given, together with percentage changes over the previous 12 months for seasonally adjusted and 3-month rate of average earnings. The main indicator of growth, is based on the annual change in the seasonally adjusted index values for the latest 3 months compared with the same period a year ago. The use of a 3month average reduces the level of volatility seen in the data on a month-on-month basis.

\section{Strengths of the AEI}

The AEl, based on monthly survey data, is a timely indicator of changes in the level of earnings.

\section{Limitations of the AEI}

The index is not adjusted for any changes in the composition of the workforce such as changes in the share of full time and part time workers, or in the share of skilled and unskilled workers. Similarly, the index does not account for changes in the number of hours worked, or any temporary factors that affect earnings.

The sample of the Monthly Wages and Salaries Survey on which the AEI is based is not designed to provide information on the level of earnings. The sample is not completely representative of the economy as firms with fewer than 20 employees are excluded, as are the earnings of self employed persons.

The AEI only covers earnings in Great Britain as earnings information is not collected for Northern Ireland and regional data are not available.

\section{LEISURE}

\section{Television Licences (Table 19.1)}

These figures are compiled by Capita Business Services Ltd. and represent the total number of annual licences in force at the end of the period. They include about 39,700 licences issued at a reduced fee to the blind but exclude an estimated 527,000 households covered by accommodation and residential care licences.

\section{UK Cinema statistics (19.2)}

Cinema admissions collected on behalf of the Cinema Advertising Association by Nielsen EDI. Admissions figures are collected on a weekly basis from virtually all cinemas in the UK.

\section{Earnings and expenditure on overseas travel and tourism (Table 19.4)}

Table 19.4 shows estimates of UK earnings from overseas visitors and expenditure by UK residents on visits abroad. The figures come from the International Passenger Survey, a sample survey of people as they enter or leave the country through the principal air, sea or tunnel routes. They exclude payments for travel to and from the UK.

An overseas visitor is defined as someone who is permanently resident in a country outside the UK and who visits the United Kingdom for a period of less than 12 months. UK citizens resident abroad for 12 months or more who visit the UK for less than a year are included in this category. Similarly, visits abroad are visits for a period of less than 12 months by people permanently resident in the UK (but who may be of foreign nationality)

Until April 1999 the IPS did not cover routes to and from the Irish Republic. All current estimates are supplemented by data provided by the Central Statistical Office in Ireland to produce the figures in the table.

\section{WEATHER}

\section{District summary (Table 20.1)}

\section{Annual summary (Table 20.2)}

Further details on weather statistics or an explanation of the methodology used in this table may be obtained from the Met Office, Fitzroy Road, Exeter, Devon, EX1 3PB. Telephone 0870 900 0100, Fax 08709005050 or email: enquiries@metoffice. com 